\title{
Eco-functionality of organic matter in soils
}

\author{
Ellis Hoffland (D) Thomas W. Kuyper • \\ Rob N. J. Comans • Rachel E. Creamer
}

Received: 11 December 2019 / Accepted: 26 July 2020 / Published online: 17 August 2020

(C) The Author(s) 2020

\begin{abstract}
Background Soil organic matter (SOM) supports multiple soil ecosystem functions, underpinned by processes such as $\mathrm{C}$ sequestration, $\mathrm{N}$ mineralization, aggregation, promotion of plant health and compound retention. We know little about the relationship between these functions and SOM quality.

Scope We aimed to develop "eco-functionality" as a framework to address questions on the relation between SOM properties and soil ecosystem functions.
\end{abstract}

Ellis Hoffland and Thomas W. Kuyper contributed equally to this work.

Responsible Editor: Ismail Cakmak.

Electronic supplementary material The online version of this article (https://doi.org/10.1007/s11104-020-04651-9) contains supplementary material, which is available to authorized users.

E. Hoffland $(\bowtie) \cdot$ T. W. Kuyper $\cdot$ R. E. Creamer

Soil Biology Group, Wageningen University, P.O.Box 47, 6700

AA Wageningen, The Netherlands

e-mail: Ellis.Hoffland@wur.nl

T. W. Kuyper

e-mail: Thom.Kuyper@wur.nl

R. E. Creamer

e-mail: Rachel.Creamer@wur.nl

R. N. J. Comans

Soil Chemistry and Chemical Soil Quality, Wageningen University, P.O.Box 47, 6700 AA Wageningen, The Netherlands e-mail: Rob.Comans@wur.nl
Conclusions Paradigm shifts in SOM research have not led to metrics for eco-functionality beyond decomposability and $\mathrm{C}: \mathrm{N}$ ratio. Recalcitrant $\mathrm{OM}$ is underresearched despite its essential role in aggregation and $\mathrm{C}$ sequestration, especially in C-saturated soils. Most soil functions are dependent on SOM decomposition and require labile compounds. We conclude that ecofunctionality is context-dependent and needs to take time scales into account. We plea for attempts to link operationally defined SOM fractions to functions in order to make SOM research more applicable.

Keywords Eco-functionality · Soil organic matter · Property-function relationship

\section{Introduction}

Soil organic matter (SOM) is accumulated, decaying debris mainly of plant origin. The plant material that enters the soil can be in a dissolved or particulate form. Dissolved inputs can be leaf and needle litter leachates, root exudates and rhizodeposits (Sokol et al. 2018); particulate plant material consists mainly of senesced or dead shoot and root litter. Soil OM is both a substrate (energy and nutrient source) for, and a product of soil microorganisms. While the input of organic material to the soil has an overwhelming plant signature, SOM gradually becomes dominated by molecules of microbial signature (Kallenbach et al. 2016). Microbial necromass is estimated to account for 30 (temperate forest soils) - $62 \%$ (grassland soils) of total soil organic 
carbon in the topsoil (Liang et al. 2019). Dissolved OM usually accounts for less than $2 \%$ of SOM (Von Lützow et al. 2007).

Soil OM research was originally focussed on soil fertility, and later on the interactions with heavy metals in the context of soil contamination. But since awareness about global warming grew in the 1980's, the focus has shifted to $\mathrm{C}$ sequestration as an opportunity for climate regulation (Fig. 1). Soil organic $\mathrm{C}$ in the upper $100 \mathrm{~cm}$ soil layer contains about $50 \%$ of the terrestrial C pool (Lal 2004). The first mention of $\mathrm{C}$ sequestration in a paper on SOM was by Thornley et al. (1991). The addition of $\mathrm{C}$ sequestration as a further soil function resulted in a gradual shift towards awareness of potential trade-offs between these two soil functions (SOM as a source of nutrients and SOM as a potential for C storage). This trade-off was most explicitly epitomized by Janzen (2006) in his paper "The soil carbon dilemma: shall we hoard it or use it?". At the time of that paper, a trade-off seemed likely as the nutrient source function needs decomposition, while the $\mathrm{C}$ storage function needs absence of decomposition.

But SOM supports more physical, chemical and biological processes sustaining vital ecosystem functions in addition to $\mathrm{C}$ sequestration and as a source of nutrients and energy for biota (Fig. 2). For the purpose of this review, we propose a framework inspired by the concept of soil-based ecosystem functions and earlier frameworks for managing soil-based ecosystem services (Bünemann et al. 2018; Schulte et al. 2014). We propose erosion protection, provision of a habitat for biodiversity, primary production, climate regulation and compound retention as soil-based ecosystem services or soil functions that are supported by SOM. Underpinning these functions are SOM-mediated processes that can be categorized into processes related to soil structure (physics), soil life (biology) and elemental cycles (chemistry).

\section{Eco-functionality of soil organic matter}

We propose the term "eco-functionality" to describe the properties of SOM suitable to serve any soil ecosystem function or service, be it SOM that is already present in the soil, or amendments. "Eco-functionality" is inspired by the concept of "bio-functionality", a term that has mainly been used in materials science and engineering to describe the biological function of materials or compounds. We propose "eco-" rather than "bio-"functionality to articulate the relevance of environmental interactions to functionality of SOM and to acknowledge that eco-functionality of SOM is contextdependent; it cannot be understood exclusively from the inherent SOM properties. A wealth of new high molecular and spatial resolution techniques has facilitated further characterization of the nature of SOM in recent years and distinction of "functional" pools in OM research is increasingly common practice (Kögel-Knabner and Rumpel 2018). We therefore consider it timely to introduce the concept of eco-functionality.

Most, if not all, functions of SOM are known to be promoted by increased quantities, yet we know little about the relationship between these functions and SOM quality. Various attempts have been made to classify SOM into contrasting conceptual pools, for instance recalcitrant vs labile, mineral-associated vs particulate, protected or occluded vs free or non-occluded, etc. These contrasts refer to the chemical, biological or physical reactivity of SOM, but not to how they support soil functions. Despite a huge body of research on SOM, there is still lack of knowledge regarding the inextricably linked chemical, biochemical, and biological factors responsible for the various functions of SOM.

Eco-functionality should include the relationship between characteristics of organic inputs and soil ecosystem functions supported. This relationship may be direct (as a result of input properties), or indirect: as a result of SOM shaping the decomposer community. Ecofunctionality should describe, at process or mechanistic scale, how SOM, depending on properties, fuels and shapes the soil microbial community and the environment surrounding those microbes, with potential knockon effects further downstream in the soil food web and on ecosystem functions. For instance, energy-rich cellulose sources are eco-functional in that they promote increased fitness of decomposers with cellulolytic enzymes, by which they can gain dominance over decomposers that depend on more simple $\mathrm{C}$ sources, as happens during fungal succession in decaying plant litter (Vivelo and Bhatnagar 2019). That shift in competitive dominance potentially scales up to soil ecosystem functions, when it contributes, for instance, to disease suppression (Bonanomi et al. 2018b).

At a more applied level, eco-functionality refers to the questions "What kind of SOM do we need for which purpose?" or, more specifically, "Which characteristics should organic amendments have to promote $\mathrm{C}$ 


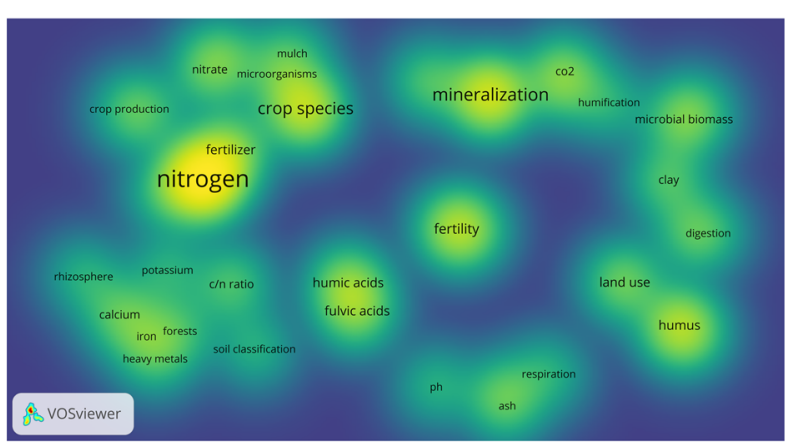

Fig. 1 Frequency and co-occurrences of keywords in scientific publications in two periods: 1911-1985 (left) and 1986-2019 (right). Records were retrieved using the query "soil organic matter" or "soil organic carbon" in Scopus. This resulted in 869 records for the period 1911-1985 and 35,953 for the period 1986-

sequestration, to restore soil structure, to retain compounds like trace elements or organo-pollutants and to prevent dispersal to water bodies, or to suppress diseases?"

\section{Aim of this paper}

This paper aims to develop the concept of ecofunctionality as a framework to address questions on the relation between SOM properties and soil ecosystem functions, both at process and at management level. We explore which SOM properties control specific functions and through which biological, chemical and physical processes. Whenever possible, we explore also how

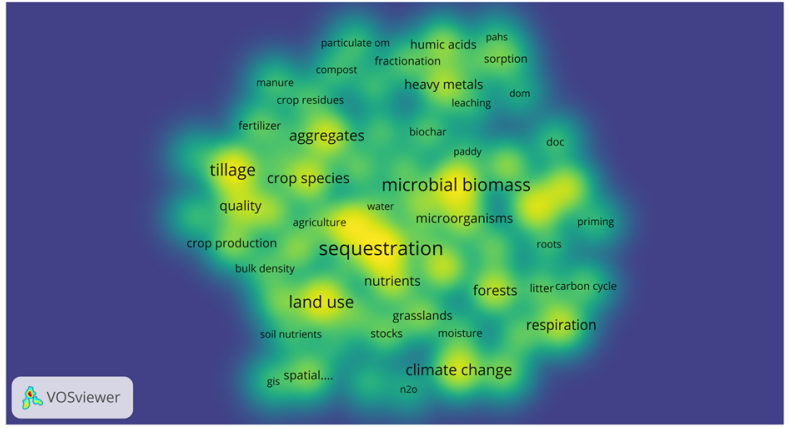

2019. The size of the keyword indicates the occurrences: the larger, the more frequent. The position indicates with which other keywords the keyword occurred on a publication. Details on methods used can be found in Supplementary Information

understanding of the property-function relationship may contribute to management of $\mathrm{OM}$ inputs, i.e. how to select application of OM with specific properties for the intended function(s). In our (first) attempt to develop this framework we aimed for a complete overview rather than an in-depth mechanistic discussion of the relationship between a few functions of SOM and its characteristics.

We first review and synthesise the state of the art on two processes (transformation and stabilization) that are essential to the development of the concept of ecofunctionality. Then we relate ecosystem functions to SOM characteristics, as much as possible according to the systematics of Fig. 2.

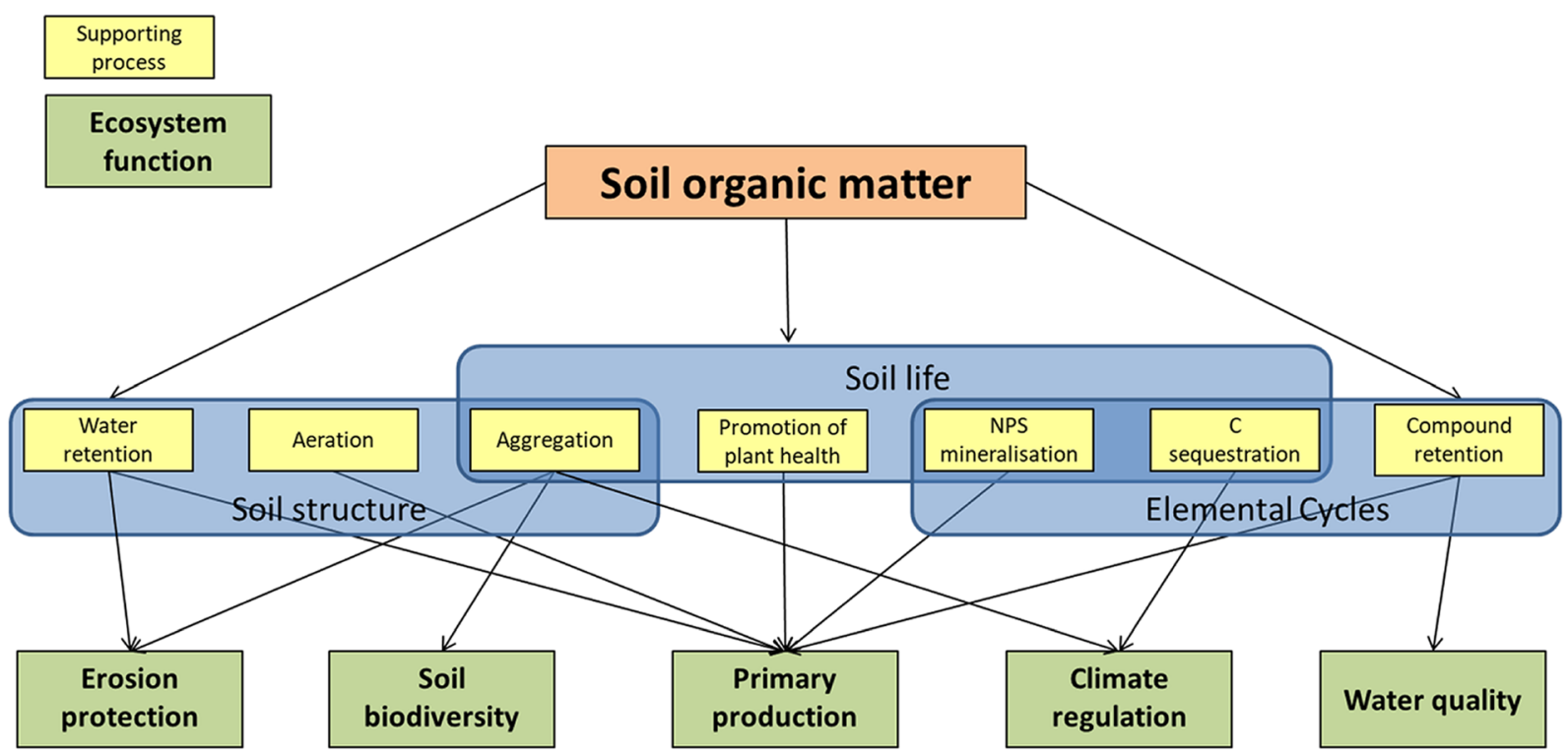

Fig. 2 Ecosystem functions of soil organic matter and the processes supporting them 


\section{Processes relevant to eco-functionality}

The transformations of organic inputs in soil during decomposition and their subsequent stabilization with other soil constituents (mineral matrix) will affect their eco-functionality. Below we will review the state of the art of these processes separately, for the sake of simplicity. But we are keenly aware that transformation affects subsequent stabilization and vice versa.

\section{Transformations}

Soil OM is a continuum of a large diversity of compounds in various states of decomposition driven by heterotrophic microbial communities. Plant residues both from above and below ground are highly variable in their chemical composition, even within ecosystems (Kögel-Knabner 2002). The rate at which the diverse compounds can be metabolized, varies from half-lives in the range of minutes for sugars, most carboxylic and amino acids once dissolved in pore water (Gunina et al. 2017), to decades to millennia for compounds that either have a low energy content and /or a high reactivity towards the mineral matrix. The ability to quickly degrade energy-rich dissolved compounds is universal among microbial species (Wallenstein et al. 2013). Larger or more complex molecules cannot be taken up by microbial cells and therefore need to be cleaved into smaller compounds by extracellular enzymes first (Burns et al. 2013). These complex molecules are associated with specific microbial taxa within their decomposer community (Bhatnagar et al. 2018). As a result of changes in OM composition during these transformations, decomposer communities change during the decomposition process (Bonanomi et al. 2019a). Degradation of complex molecules like lignin costs more energy than it ultimately yields, necessitating co-metabolic activity that provides the energy (Moorhead et al. 2013). Upon oxidative depolymerization, polymers become smaller and ultimately soluble to form the dissolved OM fraction. They also become chemically more reactive and polar, due to an increase in oxygen-containing functional (carboxylic, phenolic) groups (Kleber et al. 2015).

The soil decomposer community uses part of the $\mathrm{C}$ for its anabolism (build-up of biomass); another part is respired and disappears from the soil as $\mathrm{CO}_{2}$ (or $\mathrm{CH}_{4}$ under strongly anaerobic conditions). The balance between anabolism and catabolism (to release energy) determines
C use efficiency (CUE) of the decomposers (and, together with microbial stoichiometry (Mooshammer et al. 2014), the nutrient use efficiency as well). Novel microbial substances are synthesized during anabolism, with similar or different eco-functionalities. Microbial products accumulate as decomposition progresses: plant-derived compounds decrease (with alkanes as an exception) relative to microbial N-containing compounds (Barré et al. 2018). Microbial necromass generally has a lower energy content (Barré et al. 2016) than the plant mass that was used to assimilate this microbial biomass. The decreasing energy content of remaining organic material results in a lower microbial biomass with a decreased CUE; and hence a slower transformation of organic materials.

In addition to a lower energy content, microbial residues also have lower $\mathrm{C}: \mathrm{N}$ ratios than their initial substrate, resulting in relative $\mathrm{N}$-enrichment of SOM upon decomposition. Soil OM C:N ratios are \pm 11 (Kirkby et al. 2011) and very old (millennial pools) SOM has C:N ratios as low as 6 (Rumpel and KögelKnabner 2011), both similar to $\mathrm{C}: \mathrm{N}$ ratios of microbial biomass (C:N =6-12; (Xu et al. 2013)).

This transformation of highly diverse plant material into more uniform residual material has been referred to as the "decomposer funnel", loosely based on a concept by Swift et al. (1979). They proposed a cascade model of the biochemistry of decomposition that results in convergence of the final SOM properties. Different from the concept by Swift et al. (1979) however, convergence is now attributed to the increasingly microbial signature of decomposing OM (Fierer et al. 2009). Various studies have reported chemical convergence during decomposition: residual materials, including the DOM derived thereof, become more aromatic (Demyan et al. 2012; Sanderman and Kramer 2013), show lower C:N and lower C:P (Xu et al. 2013). Residual materials are also consistently H-depleted, have a lower energy content (Barré et al. 2016) and a higher activation energy. Convergence is corroborated by the observation that organic amendments, which can vary largely in composition, are decomposed at similar rates once they have reached a similar state of decomposition (Janssen 1984), implying similarity in their properties. This concept of the decomposer funnel, however, has not remained uncontested. Cases of divergence in chemistry during litter decomposition have been reported as well: differences in litter chemistry persisted or even also emerged during decomposition (Wickings et al. 2012) or C:N ratios diverted (Liu et al. 2016). 
The debate on the decomposer funnel is relevant in the context of eco-functionality, because convergence towards a homogeneous SOM implies that any residue would, ultimately, acquire a similar chemistry at the end of the funnel and consequently serve similar ecosystem functions. The eco-functionality of $\mathrm{OM}$ would then be determined by its state of transformation, i.e. its position along the funnel (see, for instance Cassigneul et al. (2015) for an example). While that concept may suggest that for certain functions the ability to manage that function is severely constrained, it still leaves open the possibility that the rate at which a certain residual quality with its related eco-functionality is achieved, can be under management control. For instance, fresh organic $\mathrm{C}$ inputs including labile ${ }^{1}$ components could favour functions that demand an active decomposer community that can derive sufficient energy from its transformation, whereas later in the decomposition process residues from these inputs, now with reduced energycontent but increased chemical reactivity towards the mineral matrix, have favourable effects on ecosystem functions like $\mathrm{C}$ sequestration. The duration of the various services, i.e. SOM's eco-functionality, would then depend on the continuous supply of fresh inputs, the association of intermediate decomposition products with the mineral matrix, and the interactions between these various $\mathrm{C}$-compounds. This adds the dimension "time" to the concept of eco-functionality.

\section{Stabilization}

The last decades have seen a shift in the scientific view of the persistence of SOM (Kögel-Knabner and Rumpel 2018). Three key changes of theory have been presented on persistence mechanisms for SOM: 1) There has been a change in focus from $\mathrm{OM}$ recalcitrance as an intrinsic property (intrinsic stability), determined by the chemistry of the various compounds towards a view that persistence is a result of interactions with the environment (Dungait et al. 2012; Marschner et al. 2008; Schmidt et al. 2011; Wiesmeier et al. 2019), hence a perspectival shift from stability to stabilization, defined as interactions with the soil environment that reduce, but do not stop, process rates. 2) Simultaneously there has been a

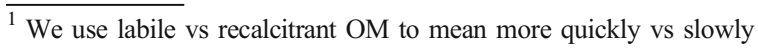
decomposable OM due to intrinsic molecular properties, sensu Von Lützow M, Kögel-Knabner I (2010) Response to the concept paper: 'What is recalcitrant soil organic matter?' by Markus Kleber. Environmental Chemistry 7: 333-335. doi: https://doi.org/10.1071/EN10085.
}

shift in perception on SOM compounds, from large highly complex polymeric molecules towards a view that emphasises that these stabilized substances consist of small molecules that show self-organization. Smaller molecules (aromatic substances, small peptides, amino sugars, phosphorylated amino acids) can self-assemble into more loosely arranged larger structures that have been interpreted as supramolecular associations (Piccolo 2002) or micelles (Hedges et al. 2000) in which material can be protected from decomposition (Sutton and Sposito 2005). And finally 3 ) there has been a shift from considering stable SOM as exhibiting a predominant plant signature towards a new view that emphasises the microbial signature of persistent SOM (Kallenbach et al. 2016). The implication of that shift is that substrates that enable a higher microbial CUE are the drivers of more rapid formation of persistent SOM (Cotrufo et al. 2013).

Stabilization links to eco-functionality of SOM in multiple ways: it contributes to aggregation, aeration, water retention, NPS mineralization, $\mathrm{C}$ sequestration and compound retention.

\section{Mineral-associated OM}

Along its way through the decomposer funnel, organic compounds can be stabilized through association with the soil's mineral phase (Lehmann and Kleber 2015; Leinemann et al. 2018). Density fractionation of soil has shown that about 50-90\% of total organic $\mathrm{C}$ can be associated with mineral surfaces, which makes it the biggest SOM fraction in mineral soils (Giannetta et al. 2018; John et al. 2005). Although stabilization is transient (Leinemann et al. 2018), the residence time of mineral-associated compounds can be orders of magnitude greater than that of those same compounds when they are not associated with minerals (Kleber et al. 2015). Dissolved C compounds can, depending on their charge, be associated with charged mineral surfaces (metal (hydr)oxides, clay surfaces and clay edges). Also the enzymes that are needed for transformation and degradation of these products can be stabilized on mineral surfaces (Kleber et al. 2015). As a result of conformational changes and attachment to active surface sites they can be inactivated, which can further slowdown decomposition of SOM. 
Aggregates

Organic matter is also stabilized through occlusion in aggregates (Angst et al. 2017a), and it is at the same time a key factor in aggregate formation and stabilization. Reported amounts of organic $\mathrm{C}$ found in aggregates vary widely, ranging from 7 to $20 \%$ (Giannetta et al. 2018) up to nearly $90 \%$ (Jastrow et al. 1996) of total SOM, depending on the fractionation method used. The protective function of macro-aggregates $(>250 \mu \mathrm{m})$ against decomposition is attributed to their capacity to spatially separate microorganisms and their extracellular enzymes from their substrates, and to limit inward oxygen diffusion (Six et al. 2002)., suggesting it is mainly particulate $\mathrm{OM}$ that is protected.

Micro-aggregates $(<250 \mu \mathrm{m})$ form a rather stable and complex system of small pores, many of them $<20 \mu \mathrm{m}$; (Rabbi et al. 2016). Iron (and aluminium) oxides, with their large surface area and their ability to bind to clay (Krause et al. 2019), silt and sand particles, and their associated SOM, are major binding agents to form micro-aggregates (Regelink et al. 2015), suggesting that micro-aggregates protect SOM from decomposition through association rather than occlusion. Microaggregates can join with other particles to form macroaggregates (Rabot et al. 2018), a process which probably needs additional, but more transient glues of a different character and of which earthworms are important drivers (Bertrand et al. 2015). Alternatively, microaggregates are formed within macro-aggregates, held together by roots (Blankinship et al. 2016; Poirier et al. 2018), fungal hyphae and organic glues produced by roots, fungi and bacteria.

\section{Soil life}

Organic matter fuels soil life so OM quality may modulate belowground communities. This may impact soil processes relevant to soil ecosystem functions. Here we focus on indirect OM quality -function relationships: how OM quality relates to soil functions through modulation of soil biota.

\section{Fungal:Bacterial ratios}

The fungal:bacterial (F:B) biomass ratio has been considered as an indicator for the activity of two pathways of the soil food web, formed by fungivores or bacterivores and their predators, respectively. Labile substrates were supposed to fuel the bacterial pathway while more lignin-rich, often woody, substrates would favour fungi because of their capacity to convert lignocellulose. Fungal-based pathways contribute more to the decomposition of old soil $\mathrm{C}$ than bacterial-based pathways (Vestergård et al. 2019), which does not necessarily mean that fungi should contribute less to decomposition of labile substrates than bacteria (De Vries and Caruso 2016). A significant contribution of fungi to decomposition of labile substrates could explain the relatively large contribution of their necromass to total micorbial necromass (Liang et al. 2019).

The wish to manage $\mathrm{F}: \mathrm{B}$ ratios in agro-ecosystems to manipulate $\mathrm{C}$ and $\mathrm{N}$ cycles has been tempting. The idea that the $\mathrm{F}: \mathrm{B}$ ratio provides crucial information on $\mathrm{C}$ cycling and soil fertility dates at least from Waksman et al. (1928). Frostegård and Bååth (1996) noted a positive relationship between $\mathrm{F}: \mathrm{B}$ biomass ratios and $\mathrm{OM}$ content of soils (i.e. $\mathrm{C}$ sequestration), without specifying directionality of that relation. Subsequently Bailey et al. (2002) suggested that the F:B biomass ratio could be used as a predictive tool for enhanced $\mathrm{C}$ sequestration: Fungal-dominated soils are supposed to sequester more $\mathrm{C}$, retain more $\mathrm{N}$ (De Vries et al. 2011) and have lower $\mathrm{N}$-mineralization rates because of the higher $\mathrm{C}: \mathrm{N}$ ratio of fungi compared to bacteria (10-15 vs. 4-6; Hodge et al. (2000)). Strickland and Rousk (2010) concluded that results are ambiguous, and that using $\mathrm{F}: \mathrm{B}$ ratios to infer the rates and controls on soil microbial processes is often not valid.

Nevertheless, F:B ratios are supposed to be dependent on the quality of organic inputs, fungi being more dominant when inputs are more recalcitrant because of their better capability to degrade lignin and other plant cell wall components (Strickland and Rousk 2010). For this reason, the $\mathrm{C}: \mathrm{N}$ ratio of organic inputs are often supposed to steer the F:B ratio, with fungi being dominant on high $\mathrm{C}: \mathrm{N}$ ratio inputs. There are, however, few examples of $\mathrm{F}: \mathrm{B}$ being managed through quality of $\mathrm{OM}$ inputs, probably because the relationships between organic-amendment quality and F:B ratios are not straightforward (Silva-Sánchez et al. 2019); F:B ratios are part of a syndrome (Wardle et al. 2004) rather than a response to one single component: higher $\mathrm{F}$ : $\mathrm{B}$ ratios are typical for infertile habitats with lower primary production rates, litter with low $\mathrm{N}$ and high lignin concentrations, and hence low decomposition rates. Moreover, fungi and bacteria are not two distinct functional groups; 
they overlap in relevant metabolic characteristics such as CUE and capacity to degrade organic compounds. Less intensively managed ecosystems (De Vries et al. 2007), or ecological agriculture with higher OM inputs compared to conventional agriculture (relying more on mineral fertilizers) often result in higher fungal abundance (Chavarria et al. 2018), but often it is impossible to distinguish OM quality effects from effects of differences in soil tillage, residue management, etc.

\section{Soil fauna}

Soil macro- and mesofauna play a critical role in many soil processes. They modulate the soil microbial community and support decomposition (the inverse of $\mathrm{C}$ sequestration), nutrient cycling and aggregation, thereby underpinning all soil ecosystem functions. There is ample literature on the role of soil macro- and mesofauna, and on how SOM or organic inputs are processed by them (Frouz 2018); their abundance and diversity is generally expected to increase with SOM content (De Graaff et al. 2019; George et al. 2017). But there is little on how SOM quality (apart from $\mathrm{C}: \mathrm{N}$ ratio as a general property of fresh organic inputs) can affect their abundance and activity. Soil OM effects can be direct (because soil organisms feed on SOM), or indirect: e.g. through SOM effects on plant or root density (Biederman et al. 2008) and, as a result, on plant C inputs (De Graaff et al. 2019). It is hard to separate direct from indirect effects since soil fauna is ultimately fuelled by net primary production.

To further elaborate the concept of eco-functionality, we treat earthworms as an example, while acknowledging that other faunal groups are important players as well. Earthworms have long been acknowledged as "ecosystem engineers" that play an important role in soil ecosystem functions, such as aggregation or structure maintenance (Angst et al. 2017b; Gong et al. 2019), SOM decomposition and nutrient cycling (Bertrand et al. 2015). Suggestions that earthworms both increase soil fertility (through increased $\mathrm{N}$ mineralization) and crop yields (Van Groenigen et al. 2014) and at the same time promote $\mathrm{C}$ sequestration in aggregates, seem to imply that earthworms can escape from the carbon dilemma. Lubbers et al. (2017) showed both earthworm-mediated increased decomposition of SOM and to a lesser extent stabilization of residue-derived $\mathrm{C}$ inside aggregates. So transformations of relatively fresh SOM induced by earthworms that dwell in the mineral soil, may result in residues that interact more strongly with the mineral matrix. Promoting earthworm populations can therefore be a tool in promoting these soil ecosystem services.

Since earthworms mainly feed on SOM, knowledge on their feeding ecology should provide tools for effective earthworm management through organic $\mathrm{C}$ inputs. Earthworms feed on dead SOM and on the decomposer microorganisms that are inseparable from that SOM. Functional group-specific gut wall-associated bacterial communities (Thakuria et al. 2010) contribute to the degradation of SOM by earthworms. Earthworms generally prefer protein-, carbohydrate- and nutrient-rich (Cesarz et al. 2016) litters. Phenolic-rich compounds become palatable only after microorganisms have degraded them (Curry and Schmidt 2007).

There are, however, few studies relating the quality of (organic C) inputs to earthworm abundance. They seem to agree that substrates with larger amounts of easily degradable C (Leroy et al. 2008) and available N (Roarty et al. 2017; Sileshi and Mafongoya 2007) promote earthworm abundance directly or via promotion of the microbial biomass on which they feed (Marhan and Scheu 2005). Also a continuous supply of food (through cover crops or intercropping) supports larger earthworm populations (Schmidt et al. 2003).

\section{Biodiversity}

Soil organisms occupy different feeding strategies. It seems therefore plausible that higher aboveground biodiversity should be linked to higher belowground biodiversity through more diverse litter and rhizodeposits. There are few papers confirming this hypothesis (Scherber et al. 2010; Venter et al. 2016); most studies focus on abundance and activity of soil organisms rather than diversity. But direct evidence for diverse inputs explaining the correlation between aboveground and belowground biodiversity is lacking, because increased aboveground biodiversity often affects other modulators of soil biodiversity as well, such as primary production (Zak et al. 2003), ground cover and temperature regulation, moisture conditions (Venter et al. 2016) and (in comparisons of more and less diverse agricultural systems) tillage and residue management.

Biodiversity generally increases with environmental heterogeneity. Soils are heterogeneous at various scales by default. Aggregation creates heterogeneity at the scale of $\mu \mathrm{m} / \mathrm{mm}$ at which environmental conditions 
(moisture, oxygen) and possibly also SOM quality differ from the bulk soil. Aggregates provide a conducive microhabitat for activity of a microbial community that is different from that in the bulk soil (Bach et al. 2018). So organic amendments that promote aggregation, directly or indirectly through earthworm activity (Gong et al. 2019) are likely to promote soil microbial diversity as well.

\section{Aggregation, aeration, water retention}

Aeration and water retention are both a result of aggregation, which is commonly used as an indicator of soil structure. Soil structure defines the network of pores and thereby porosity, water retention and aeration, and has a key function in stabilization of SOM.

Organo-mineral (particularly Fe oxide) associations are building units within the system of micro-aggregates (Hernandez-Soriano et al. 2018; Regelink et al. 2015; Totsche et al. 2018). Totsche et al. (2018) suggested a continuum from mineral-associated $\mathrm{OM}$ to micro-aggregates. So it seems safe to assume that organic $\mathrm{C}$ inputs that promote association of SOM with minerals, are ecofunctional in promoting soil structure as well. Accordingly, operationally defined humic substances (humic and fulvic acids) are correlated with water stable aggregates (Kimura et al. 2017; Polláková et al. 2018) which could be explained by their capacity to bind to mineral surface (Weng et al. 2006).

Debris of bacterial and fungal cell walls can act as a nucleus for micro-aggregate formation (Miltner et al. 2012). Also living bacteria interacting with mineral surfaces play an important role in formation of larger micro-aggregates $(>20 \mu \mathrm{m})$, probably dependent on the surface charge and hydrophobicity of their cells, and their production of extracellular polysaccharides (Hernandez-Soriano et al. 2018; Krause et al. 2019; Mizuta et al. 2015; Totsche et al. 2018). Microbial products (extracellular polysaccharides, mucilage, reactive cell wall material, glomalin) can also play a dominant role in macro-aggregate formation, as evidenced by synchrony between increased soil respiration and macro-aggregate formation upon addition of organic amendments (Mizuta et al. 2015). Macro-aggregates have wider and better connected pores than micro-aggregates. They are also more transient than microaggregates.
In general, increased SOM (Panakoulia et al. 2017; Regelink et al. 2015) and organic amendments (Mangalassery et al. 2019) are associated with increased aggregation and hence plant water availability (Eden et al. 2017). Although the capacity of organic amendments for aggregate formation seems to vary (Dai et al. 2019), there is little comprehensive knowledge on the relationship between the nature of organic inputs and aggregate formation. Organic inputs can have multiple functions in promoting aggregation: they can act as a binding agent themselves, promote microorganisms that serve as or produce binding agents or because they can interact with other compounds and affect their stabilizing abilities (Erktan et al. 2017), or support meso- and macrofauna involved in aggregation.

Particulate OM has been shown to act as a nucleus for effective macro-aggregate formation in an artificial soil within a month (Bucka et al. 2019). This is potentially facilitated by microbial products that develop on particulate OM surfaces and dissolved SOM as a result of decomposition. Labile dissolved SOM promoted formation of aggregates (macro-aggregates less efficiently than micro-aggregates) within this soil (Bucka et al. 2019). This is consistent with the finding that amendments with labile $\mathrm{C}$ promote relatively rapid but transient water-stable macro-aggregate formation through promotion of bacteria producing extracellular polysaccharides. More recalcitrant material would provide a slow but more continuous source of substrate to microorganisms, resulting in slower but more persistent (>300 days) macro-aggregation (Sarker et al. 2018).

Stability of aggregates depends to some extent on their wetting properties, which is influenced by hydrophobic or amphiphilic compounds adsorbed to surfaces of aggregates (Totsche et al. 2018). The resulting hydrophobic coating would prevent water infiltration into aggregates and slaking of aggregates.

\section{Promotion of plant health}

\section{Disease suppression}

Bonanomi et al. (2018a) recently reviewed the functionality of organic amendments to suppress diseases. They concluded that there is a "lack of knowledge regarding the chemical, biochemical, and biological factors responsible for effective organic amendment-based disease suppression", a main reason being an inadequate 
"understanding of the feeding preference, e.g., during the saprophytic phase of either pathogenic or beneficial microbes". Nevertheless, some organic amendments are known to be effective for disease suppression. For instance glucosinolates from green manures of the Brassicaceae, are precursors of toxic isothiocyanates. Their mode of action is supposed to be direct, nematicidal (Vervoort et al. 2014). Most other OM effects on disease suppression, however, are indirect: through, for instance, effects on the activity of saprotrophic, nonpathogenic soil biota.

A meta-analysis to characterize suppressive amendments found very little parameters consistently related to disease suppression (Bonanomi et al. 2010). The C:N ratio of amendments was poorly correlated with suppressiveness, and their decomposition could increase or decrease suppressiveness. Similarly, in an attempt to relate characteristics of dissolved OM (the bioavailable source of $\mathrm{C}$ for soil microorganisms) to soil general disease suppression, no consistent relation was found (Straathof 2015). Suppression of the root rot-causing fungus Rhizoctonia solani by volatiles produced by the soil microbial community in Dutch soils was positively correlated with SOM content, microbial biomass and proportion of litter saprotrophs in the microbial community (Van Agtmaal et al. 2018) which partly corroborates the finding of Bonanomi et al. (2010) that general microbial parameters (such as respiration, microbial biomass) are more informative predictors of disease suppression rather than chemical ones.

Plant-growth promotion

Soil OM has been reported to be beneficial for plant, and especially root growth. Beneficial effects on shoot performance have also been reported and some commercial products, such as humic substances, are intended for foliar application (Olaetxea et al. 2018). Lyons and Genc (2016), however, reported that most of the evidence for beneficial effects is anecdotal rather than rigorously mechanistic. Elucidating relations between properties of those substances and their ecofunctionality has been difficult, partly for analytical reasons as classical extraction of humic substances may provide a biased view of properties of the various fractions that could then be individually assessed. There is also uncertainty whether the properties of those extracts are due to the chemical structure of these humic substances or whether microbial hormones are entrapped in these supramolecular associations. It was also shown that the $\mathrm{pH}$ of the humic extract exerted different hormonal effects: acid extracts exhibited auxin-like activity (i.e. effects on the size and architecture of the root system), whereas at neutral $\mathrm{pH}$ the extract exhibited gibberellin-like activity (i.e. conversion of starch into sugars, and with auxins stimulation of stem elongation). Most attention to date has been given to auxins, especially indole acetic acid (Nardi et al. 2018). From a management perspective it has become clear that the properties of these organic substances are not or hardly related to their provenance (Garciá et al. 2016). Plants that benefit from these substances may also be more tolerant or resistant to soilborne pathogens.

\section{Elemental cycles}

Understanding of the C:N:P stoichiometry of stabilized, mineral-associated OM is relevant in the context of ecofunctionality because it might have repercussions for management of elemental cycles such as $\mathrm{C}$ sequestration and $\mathrm{N}$ mineralization. If, for instance, proteinaceous compounds would dominate mineral-associated $\mathrm{OM}$ (Sollins et al. 2006), this would require labile, N-rich inputs (hence material that can be rapidly metabolized by decomposer microbes) for rapid stabilization of SOM, which would impact $\mathrm{N}$ mineralization.

Sollins et al. (2006) and Kleber et al. (2007) proposed an "onion" or "zonal" multilayer model for mineralassociated OM, which was confirmed by others (Coward et al. 2019; Gao et al. 2018). This model assumes layers of organic compounds with different properties. In the inner (contact) zone, organic compounds are tightly bound at discrete areas of mineral particles (Kopittke et al. 2018) well protected against degradation. Depending on the type of surface and its $\mathrm{pH}$-dependent charge, different functional groups of SOM can bind to minerals. Iron- and aluminumoxyhydroxides are relatively good predictors of SOM content (Rasmussen et al. 2018). At typical soil pH conditions ( $\mathrm{pH}=4-6)$ their net charge is positive. Functional groups of $\mathrm{OM}$ that are negatively charged at this pH may bind directly to their surface (Weng et al. 2008). These are predominantly carboxylate (Kleber et al. 2015), polar aromatic/phenolic (Kramer et al. 2012; Moon et al. 2019) and polyaromatic C (Yeasmin et al. 2017) groups with a relatively high but not further 
specified C:N ratio (Coward et al. 2019). But also phosphorylated peptides (Heckman et al. 2018), with a low $\mathrm{C}: \mathrm{N}$ may bind to these surfaces. Planar phyllosilicate surfaces, with their negative, $\mathrm{pH}$ independent charge, would selectively bind $\mathrm{N}$-containing proteinaceous material and amino acids (Moon et al. 2019) material through protonated amide groups (Kopittke et al. 2018; Yeasmin et al. 2017).

The next more hydrophobic layer in the zonal model consists of amphiphilic, proteinaceous compounds (Kleber et al. (2007), also contributing to the low C:N ratio of mineral-associated OM. Highly aliphatic, oxidized compounds can equally enter this hydrophobic layer (Coward et al. 2019). The outer kinetic zone is believed to consist of loosely bound compounds experiencing relatively more rapid exchange with the surrounding soil solution, leading to minor protection against microbial decomposition and short residence times. Coward et al. (2019) suggested that N-rich aliphatic compounds are in this third layer.

\section{Carbon sequestration}

The notion that old (centennial to millennial scales) SOM is not necessarily inherently stable, but stabilized instead through association of microbial compounds with mineral surfaces, led to the hypothesis that labile plant compounds, such as leaf leachates and root exudates, which are more efficiently utilized by microorganisms than structural compounds, are the main precursors of stable SOM (Cotrufo et al. 2013). Consequently, the $\mathrm{C}$ and $\mathrm{N}$ use efficiency of the decomposer microbial community that such substrates enable, and thus the quality of organic inputs, together with the nature of the mineral surfaces would govern the rate of C stabilization.

This raises important questions on the ecofunctionality of organic $\mathrm{C}$ inputs to promote $\mathrm{C}$ sequestration depending on timescales. Cotrufo et al. (2013) hypothesized that, although labile litter with a higher microbial $\mathrm{C}$ use efficiency will initially decompose faster, over the longer term a higher fraction of these labile inputs than of recalcitrant inputs will accumulate in soil. Unfortunately, their paper was not explicit about timescales, neither are we aware of studies that allow quantification of that scale. For management purposes, in relation to for instance the 4-per-1000 initiative (https://www.4p1000.org/), it would be necessary to know the timescale after which labile inputs are more important for persistence of SOM than the recalcitrant inputs. This timescale may be dependent on the level of C saturation (Six et al. 2002). If the soil becomes Csaturated, the functionality of recalcitrant SOM to sequester $\mathrm{C}$ might become higher. It would be a major challenge to further develop and operationalise this, potentially context-dependent, metric of efficiency of SOM formation as this would allow quantification of SOM properties for the specific function of sequestration.

\section{Nutrient mineralization}

One of the major ecosystem functions and services of SOM (Feller et al. 2006) relates to it as a source of nutrients and its subsequent use for plant nutrition and food security. Several recent meta-analyses have highlighted the role of nutrients from SOM and/or organic inputs in crop production (Hijbeek et al. 2018; Hijbeek et al. 2017; Oldfield et al. 2019). Both the rate at which nutrients can be mineralized and their amounts released per unit material are relevant properties from an eco-functionality perspective.

The $\mathrm{C}: \mathrm{N}$ ratio (or $\mathrm{C}: \mathrm{P}$ ratio) is probably the most simple metric for eco-functionality with regard to nutrient supply. As a rule of thumb, decomposition of SOM with a $\mathrm{C}: \mathrm{N}$ ratio $<30$ is supposed to produce mineral $\mathrm{N}$ (Bonanomi et al. 2019b). The general usefulness of the $\mathrm{C}: \mathrm{N}$ ratio derives from the fact that high litter $\mathrm{N}$ and low litter lignin are usually correlated (Dias et al. 2017; Freschet et al. 2012) and hence that organic inputs with $\mathrm{C}: \mathrm{N}<30$ are both rapidly degraded and release sufficient $\mathrm{N}$ per unit $\mathrm{C}$ degraded. However, the paradigm of using $\mathrm{C}: \mathrm{N}$ ratios to infer the rates and controls on $\mathrm{N}$ mineralization is not always valid:

- Energy-rich compounds with a C:N ratio favourable for $\mathrm{N}$ mineralization $(<30)$, may be protected from decomposition because of mineral association. In fact, some of the mineral-associated OM has extremely $\mathrm{C}: \mathrm{N}$ ratios as low as 4-6.

- High C:N ratio as a predictor for immobilization is only applicable to cases where degradation is $\mathrm{N}$ limited, but not to cases where decomposition is Climited or rather energy-limited.

- More stable organic $\mathrm{C}$ products such as compost and old SOM have a low C:N ratio (Rumpel and KögelKnabner 2011), based on which substantial N 
release is predicted. But their relative decomposition rate is low, which decelerates mineralization.

- The decomposer community might be able to selectively decompose ("mine") moieties with a $\mathrm{C}: \mathrm{N}$ ratio different than the average $\mathrm{C}: \mathrm{N}$ ratio of a compound. Alternatively, when organic substances are supramolecular associations with an average high $\mathrm{C}: \mathrm{N}$ ratio, they can disassemble into compounds with lower $\mathrm{C}: \mathrm{N}$ ratios that are more degradable (Straathof et al. 2014). Our reading of the literature suggests that some selective mining exists, with the $\mathrm{C}: \mathrm{N}$ ratio of the specifically mined material being around 6 (Murphy et al. 2015).

Nevertheless, the C:N ratio appears to be a suitable predictor for $\mathrm{N}$ mineralization from labile organic $\mathrm{C}$ that is easily accessible for microorganisms (Bonanomi et al. 2019b). However, it fails for more stable SOM, whether it is energy-poor and / or mineral-associated.

Eco-functionality of SOM in relation to nutrient supply should also have a time dimension. When nutrients that are released through decomposer activity are not in sync with plant demand, losses can occur. The relative decomposition rate of SOM is therefore an important metric, too. From the perspective of synchronization of nutrient release during decomposition with plant demand for those released nutrients, it could be envisaged that there is a difference between a direct route (where $\mathrm{N}$ is immediately mobilized after the critical C: $\mathrm{N}$ has been reached) and $\mathrm{N}$ that is first immobilized in microbial tissue and subsequent turnover of that microbial mass (through faunal grazing, or other forms of microbial turnover). Mixing inputs of different qualities can lead to non-additive effects (Gartner and Cardon 2004) and could be instrumental in synchronization of nutrient mineralization and plant demand. There are studies reporting that increased litter diversity promotes $\mathrm{N}$ mineralization (Cong et al. 2014). A recent meta-analysis, however, did not identify any general pattern in the effects of mixing litters on decomposition compared to single litters (Porre et al. 2020). Implications for management of $\mathrm{N}$ mineralization through mixing are unknown, as a far as we are aware.

\section{Compound retention}

Soil OM functions as one of the major reactive surfaces that control the retention of essential metal macro- and micronutrients, potentially toxic heavy metals, and organic pollutants. As a consequence of retention and in the case of co-metabolism of organic pollutants during organic matter transformations, SOM reduces the presence of these compounds in the soil solution, thereby limiting their mobility for transport to ground- and surface water, as well as their bioavailability. This process has been referred to as the soil function of water purification. In this section we concentrate on retention of trace elements, noting that similar principles apply to cationic, water-soluble pesticides (Conde-Cid et al. 2019) as SOM, especially at high $\mathrm{pH}$ and high SOM content, is the main factor contributing to cation exchange capacity.

The strong functioning of SOM in the retention of trace elements has been demonstrated by both analytical studies and validated geochemical models. Sequential chemical extraction of soil samples has frequently revealed the dominant occurrence of cationic trace elements in the SOM fraction. Although the selectivity of these classical extractions can be challenged (i.e. their ability to fully distinguish between organic and inorganic trace element fractions), recent measurements by extended X-ray absorption fine structure spectroscopy (EXAFS), which enables identification of specific chemical bonding, demonstrated predominant association with $\mathrm{SOM}$ for trace metals such as $\mathrm{Fe}, \mathrm{Cd}, \mathrm{Cu}$ and Zn (Gustafsson et al. 2007; Löv et al. 2017; Sarret et al. 2004; Strawn and Baker 2008).

Cation binding to SOM belongs to the major processes that are considered in geochemical modelling of the retention of major and trace elements in soils. These models are frequently used to predict the magnitude of element retention and the relative contribution of different minerals and reactive surfaces to this soil function. In particular so called "multi-surface" or "assemblage" models (Groenenberg and Lofts 2014) that combine separate mechanistic complexation models for the different reactive organic and mineral surfaces (and their related thermodynamic binding parameters) in soils, have been successfully used for this purpose. The most advanced models for ion binding to SOM are based on ion-complexation with both the carboxylic and phenolic functional groups, with binding capacities and heterogeneous affinity distributions that reflect the complex and diverse composition of SOM, derived from experiments with isolated humic and fulvic acids (Gustafsson 2001; Kinniburgh et al. 1996; Tipping et al. 2011). These models are based on the premise that humic and fulvic acids are the major reactive fractions of SOM with 
regard to its binding properties, a premise that is currently hotly debated (Janzen 2019; Kleber and Lehmann 2019; Olk et al. 2019). Focusing on the retention function of SOM, we note that models for proton and metal binding to SOM, based on parameters derived from isolated humic and fulvic acids, enable adequate predictions of the solid/liquid partitioning of a wide range of trace metals in whole-soil samples (Dijkstra et al. 2004, 2009; Duffner et al. 2014; Groenenberg and Lofts 2014; Tiberg et al. 2018). These modelling studies also generally confirm direct measurements that the binding of trace metals to the soil solid phase is largely controlled by SOM. However, the fact that these models provide adequate predictions of the retention properties of SOM cannot be taken as direct evidence that humic and fulvic acids are discrete molecular entities of SOM. Some studies have shown that humic substances are in fact supramolecular associations of smaller molecules, rather than polymeric macromolecules (Piccolo 2002; Sutton and Sposito 2005). But the generic binding properties of these substances may suggest that this supramolecular arrangement results in overall binding properties that are meaningful for interpretation of the retention function of SOM.

Similar to trace metals, retention of cationic pesticides depends on density and ( $\mathrm{pH}$-dependent) charge of functional groups that provide H-bonding, such as carboxylates and phenolic groups (Gros et al. 2017). Soil $\mathrm{OM}$ is considered the primary adsorbent of non-ionic pesticides, which are incorporated in the hydrophobic core of humic substances. The reactivity of SOM towards these hydrophobic pesticides and organic pollutants is negatively correlated with the ionization of carboxylic groups (Gondar et al. 2013) and resulting polarity and positively correlated with its aromaticity (Tanaka et al. 2005).

\section{Conclusions and outlook}

As far as we are aware this is the first attempt to link properties of SOM with the functions and ecosystem services that it provides. While earlier authors (e.g., Feller et al. (2006)) have sketched the ecosystem services by SOM, such listings did not explicitly consider potential trade-offs between the different functions, and hence they were unable to differentiate among different constituents of SOM. Some ecosystem services, however, need to combine both using and hoarding $\mathrm{C}$ - where SOM constitutes both the food for soil life and creates the habitats for that soil life. By disentangling the various elements it would seem, at least theoretically, possible to link specific ecosystem functions to specific $\mathrm{C}$ fractions. This idea has been around for a long time in more simplistic forms, for instance that labile $\mathrm{C}$ with a low $\mathrm{C}: \mathrm{N}$ ratio would mainly serve the use-function, while the more stable (less energy-rich, 'recalcitrant') $\mathrm{C}$ with a high $\mathrm{C}: \mathrm{N}$ ratio serve the hoard-function.

\section{Metrics of eco-functionality}

Organic matter can be qualified by an increasing diversity of techniques (Kögel-Knabner and Rumpel 2018). Nevertheless, summarizing our literature review (Table 1), the most widely used metrics to relate OM quality to function, still somehow have to do with decomposability, i.e. the dichotomy of labile vs. recalcitrant compounds. This metric reappears in microbial $\mathrm{C}$ use efficiency, which is correlated with the degradability of the $\mathrm{C}$ sources, which is a function of parameters such as molecular weight, structural complexity, energy density. More refined classifications, based on, for instance solubility, O:C versus $\mathrm{H}: \mathrm{C}$ ratios, aromaticity, functional group density are not commonly used, which does not necessarily mean that these parameters would not be useful in the context of eco-functionality. The first three can be done routinely; functional group densities can be determined by proton titrations, which is easier for carboxylic groups than for phenolic groups because of the high pKa values of the latter.

For nutrient cycling from organic inputs, the $\mathrm{C}: \mathrm{N}$ ratio is still the most widely used indicator. When SOM ages, however, $\mathrm{C}$ : $\mathrm{N}$ becomes increasingly disconnected from nutrient cycling. The lowest $\mathrm{C}: \mathrm{N}(6)$ relates to material most strongly associated with the protected pool and hence contributes to $\mathrm{C}$ storage and soil structure rather than to cycling. For $\mathrm{C}: \mathrm{P}$ the same considerations apply.

Eco-functionality of labile organic matter

Labile SOM (or inputs consisting thereof) is on a fast track through the decomposer funnel to become microbial biomass, microbial products and microbial necromass. These, in their turn, support all soil functions through a variety of soil processes (Table 1). For soils to function, SOM needs to be (at least partly) decomposed (i.e. "used"). 
The processes supported by labile SOM are typically processes relevant on a short $(<1 \mathrm{yr})$ timescale. Some require decomposition to $\mathrm{CO}_{2}$ and mineral nutrients, whereas adsorption to soil mineral surfaces is essential to other processes (Table 1). Stabilization onto mineral surfaces is not permanent, however, rates of exchange have not been clearly quantified (Kaiser and Kalbitz 2012; Leinemann et al. 2018). It is likely that at least part of mineral-associated OM is continuously desorbed and replaced, depending on environmental conditions (for instance presence of root exudates, redox shifts (Han et al. 2019; Keiluweit et al. 2015)). As a result it will become available for microbial decomposition, i.e. it is still part of the C cycle and certainly not "hoarded" (Janzen 2006). So both soil ecosystem functions that require decomposition and those that require stabilization by adsorption to mineral surfaces need maintenance by input of labile organic inputs.

\section{Eco-functionality of recalcitrant organic matter}

The eco-functionality of more recalcitrant SOM seems in danger of being overlooked as a result of the recent wealth of literature on mineral associations with labile SOM (Cotrufo et al. 2019). The notion that persistent SOM is stabilized, mineral-associated OM mainly of microbial origin, has moved attention in recent literature away from plant inputs that are only slowly degraded. But recalcitrant plant litter is quantitatively an important component of SOM: still 25-50\% of GC-MS peak area can be of plant origin after $50 \mathrm{yr}$ bare fallow in former grassland without fresh inputs (Barré et al. 2018).

It is obvious that recalcitrant SOM, on a slower track through the decomposer funnel, is important in reducing soil bulk density and improving soil structure and rootability, thereby serving primary production and most other soil functions (Fig. 2). It is likely that this partly decomposed particulate OM fraction has intermittently been incorporated in, and is an essential building block of (more persistent macro-)aggregates (Sarker et al. 2018; Totsche et al. 2018). As such, it is essential in processes supporting many, if not all soil ecosystem functions (Table 1). Although overall persistence of SOM may not be a function of its molecular structure (Schmidt et al. 2011), the concept of inherent recalcitrance may still apply to this highly essential fraction of SOM.
Context-dependency of eco-functionality

The timescale at which recalcitrant SOM is functioning to serve soil ecosystem functions, is, apart from inherent SOM characteristics, also highly context dependent. It is subject to all well-known modulators of the decomposition rate. Eco-functionality of labile inputs also shows context dependency: In a soil with a large saturation deficit, addition of labile substances, which results in high CUE, rapidly increasing microbial biomass and subsequently microbial necromass, can contribute to enhanced mineral-associated and hence more persistent SOM. However, at levels much closer to the saturation level, the same compounds could act as energy source for microbes that use this source for co-metabolism with more structurally complex compounds resulting in $\mathrm{C}$ losses from that system through a process referred to as priming. The inverse could be true for inherently recalcitrant SOM: in C-saturated soils it may be functional in sequestering C (Cotrufo et al. 2019; Lavallee et al. 2020). A similar process could happen with deep soil C. At low C concentrations (and hence low densities of decomposer microbes and their enzymes) deep soil $\mathrm{C}$ may escape from decomposition and give rise to the optimistic view that additional $\mathrm{C}$ can be stored through the use of plants with deeper roots. But as root density increases, and $\mathrm{C}$ inputs from living and dead roots result in enhanced microbial and enzymatic abundance, random interactions will occur more frequently, putting limits of deep soil C storage (Gleixner 2013). In fact, Woolf and Lehmann (2019) even suggested that feedbacks between substrate availability and microbial biomass, rather than mineral protection per se, explain long-term persistence of SOM.

There may be a lesson learnt from the history of the concept recalcitrance (Kleber 2010). It has become evident that searching for the operationalization of recalcitrance (in the meaning of resistance to microbial degradation) was elusive and that every concept of recalcitrance implied context-dependency and environmental interaction. Ultimately every organic molecule can, provided the right biological and physico-chemical conditions, be fully degraded to the highest oxidation state to form atmospheric $\mathrm{CO}_{2}$. Therefore every molecule could, in principle and provided the right unconstraining environmental context, contribute to the full suite of functionalities that are attached to SOM, despite differences in degrees and rates. 
Table 1 Organic matter quality to serve soil ecosystem functions. The time scales refer to $<1$ year (short); $1-50 \mathrm{yr}$ (intermediate) and $>50 \mathrm{yr}$ (long)

\begin{tabular}{|c|c|c|c|}
\hline $\begin{array}{l}\text { Soil ecosystem } \\
\text { function }\end{array}$ & ing Process & Metric & Putative mechanism \\
\hline
\end{tabular}

Climate regulation

C-sequestration

Chimate regulation

(1)

Erosion protection

Aggregation

Soil biodiversity

Aggregation

Primary production

Plant health promotion

\section{Activation energy and / or likely $\mathrm{C}$ use efficiency \\ Decomposability (labile vs recalcitrant)}

Aromaticity (aromatic to aliphatic)

Thermal stability, oxidition resistance

$\mathrm{C}: \mathrm{N}$ ratio

Solubility (dissolved vs particulate)

Charge (negative - positive)

Density of functional groups

\section{Wetting properties}

See metrics under Csequestration

Decomposability (labile vs recalcitrant)

\section{Wetting properties}

Humic and fulvic acids

Solubility

See under aggregation

See above

Decomposability (labile vs recalcitrant)

Decomposability (labile vs recalcitrant)
Material with high $\mathrm{C}$ use efficiency promotes production of microbial compounds stabilized through mineral association

Fast decomposition for fast production of microbial biomass and necromass to stablize on mineral surfaces; Inherently recalcitrant $\mathrm{OM}$ to promote aggregate-mediated protection against decomposition

Both seem to contribute in different ways; Interm. - long literature suggests that oldest SOM is both more aromatic or more aliphatic than fresh material, so possibly classification is too coarse

Higher for more persistant SOM

Long

Binding to minerals (phyllosilicates, metaloxides). C:N ratio of old, protected $\mathrm{OM}$ is low $(=<12)$

Dissolved OM for exchange with and stabilization on mineral surfaces;

Long

Long particulate OM for protection in aggregates and stability based on inherent recalcitrance

Binding to minerals (phyllosilicates, metaloxides)

Carboxylate, aromatic groups to bind to metaloxides, amide groups to bind to phyllosilicates

Amphiphilic molecules to form the second Interm. zone of mineral-associated $\mathrm{OM}$

Association of OM with mineral surfaces is Long essential to aggregation

Fast carbohydrate and protein rich litters Short support faunal activity that promote aggregation

Sustained promotion of a microbial Long community producing binding agents on recalcitrant material for persistent aggregation

Hydrophobicity reduces aggregate wetting and increases stability

Can bind to mineral surfaces

Rapid bacterial production of binding Short agents from dissolved OM

The pore network to retain water is defined Long by aggregation

Aggregates provide diverse micro-environments

Different pools select for different microbial and faunal guilds

Fast pools allow microbial activity and build-up of saprotrophic competitors 
Table 1 (continued)

\begin{tabular}{|c|c|c|c|c|}
\hline $\begin{array}{l}\text { Soil ecosystem } \\
\text { function }\end{array}$ & Supporting Process & Metric & Putative mechanism & Time scale \\
\hline & & $\begin{array}{l}\text { (Precursor of) toxic } \\
\text { compounds } \\
\text { Hormones }\end{array}$ & $\begin{array}{l}\text { with pathogens; recalcitrant OM } \\
\text { (compost) may also have an effect. } \\
\text { Nematicidal (for instance glucosinolates) }\end{array}$ & Short \\
\hline & & Hormones & Stimulation of root (and shoot) growth & \\
\hline & $\begin{array}{l}\text { Nutrient } \\
\text { mineralisation }\end{array}$ & $\begin{array}{l}\text { Activation energy and / or } \\
\text { likely } \mathrm{C} \text { use efficiency }\end{array}$ & $\begin{array}{l}\text { If high } \mathrm{C} \text { use efficiency also means high } \mathrm{N} \\
\text { use efficiency }\end{array}$ & Long \\
\hline & & $\mathrm{C}: \mathrm{N}$ ratio, $\mathrm{C}: \mathrm{P}$ ratio & $\begin{array}{l}\text { For fresh litter, low C:nutrient ratios means } \\
\text { quick mineralisation. }\end{array}$ & Short \\
\hline & & Relative decomposition rate & $\begin{array}{l}\text { Depending on } \mathrm{C}: \mathrm{N} \text { ratio: fast or slow } \\
\text { mineralisation }\end{array}$ & Short - interm. \\
\hline & Purification & $\begin{array}{l}\text { Activation energy and / or } \\
\text { likely C use efficiency }\end{array}$ & $\begin{array}{l}\text { Co-metabolic degradation of } \\
\text { organo-pollutants with high } \mathrm{C} \text { use effi- } \\
\text { ciency is enabled }\end{array}$ & \\
\hline & Water retention & See aggregation & $\begin{array}{l}\text { The pore network to retain water is defined } \\
\text { by aggregation }\end{array}$ & Long \\
\hline & Aeration & See aggregation & $\begin{array}{l}\text { The pore network to retain air is defined by } \\
\text { aggregation }\end{array}$ & Long \\
\hline \multirow[t]{2}{*}{ Water quality } & Compound retention & $\begin{array}{l}\text { Charge, functional group } \\
\text { density }\end{array}$ & $\begin{array}{l}\text { Cation adsorption through electrostatic and } \\
\text { covalent interactions, } \mathrm{H} \text {-bonding }\end{array}$ & Short \\
\hline & & Polarity, aromaticity & $\begin{array}{l}\text { Hydrophobic compounds bind less to polar, } \\
\text { and more to SOM which is more } \\
\text { aromatic. }\end{array}$ & Short \\
\hline
\end{tabular}

Context-dependency is also relevant in another respect. With the increased focus on persistent SOM for $\mathrm{C}$ sequestration, we may have developed a focus on processes that stabilize soil $\mathrm{C}$ while neglecting processes that destabilize soil C. In many cases the same processes can be responsible for stabilization and destabilization. Earthworms both create and destroy macro-aggregates; root exudates can be efficiently used by microbes and hence form material for microbial biomass and necromass that can become mineral-associated, but root exudates can also prime the breakdown of old SOM and / or desorb mineral-associated OM (Bailey et al. 2019). So from a management perspective we should, in case we want to increase $\mathrm{C}$ sequestration, both look at management forms that increase and reduce stabilization.

The way forward

There are still a lot of unknowns that limit our understanding of the relationship between SOM composition and soil functioning. The question 'which OM inputs do I need to support a specific soil function?' remains difficult to answer. Despite three paradigm shifts in SOM research there is still much to be gained from the perspective of SOM management for soil ecosystem services.

The recognition that separation of functional groups of SOM as a prerequisite to study SOM (Kögel-Knabner and Rumpel 2018) has inspired the development of a plethora of fractionation methods. These divide SOM into compounds that are more homogeneous than the total. In the context of eco-functionality of SOM these fractions are relevant only if they contribute differentially to soil functions. Most fractionation techniques so far result in operationally defined fractions rather than functional pools. In combination with novel analytical techniques these fractionation methods have furthered our understanding of "what sits where".

Should that lead to despair? We do not think so. A way forward could be to relate the operationally defined fractions to soil functions or processes, similar to Poeplau et al. (2018) who evaluated which fractionation methods divides SOM into fractions with distinct turnover rates. Similarly, considering specific functional groups in humic substances rather than bulk SOM properties has led to substantial progress, when humic and fulvic acids (i.e. operationally defined fractions) were meaningful in predicting the behaviour of toxic heavy-metal cations. Another promising 
approach could be to distinguish the relative importance of mineral-associated $\mathrm{OM}$ and particulate $\mathrm{OM}$ for various soil functions and relate that to required characteristics of organic inputs (Cotrufo et al. 2019; Lavallee et al. 2020). A balance needs to be found between simplicity (as little fractions as possible) and meaningfulness in relation to functionality. We also plea for an integration between soil biology, chemistry and physics: many of the SOMmediated processes supporting soil functions (Fig. 2) require cooperation across disciplines (Baveye and Wander 2019).

We see a parallel to the development of other scientific disciplines such as plant science and microbiology, which all started answering the questions "what is out there" and "how to create order in complexity" before questions "what does what" could be addressed. The vastly complex nature of SOM, in combination with our limited abilities to characterize and classify its meaningful pools, has hampered progress. But new methodological approaches are emerging rapidly that can be used to further explore and unravel the complexity of SOM. These will enable us to identify and explain patterns in this complexity. This should provide a strong scientific basis for applicable SOM science underpinning the concept of eco-functionality and relevant to SOM management for soil ecosystem services.

Acknowledgments We are grateful to Dr. Ellen Fest (Wageningen UR Library) for literature analysis. We also acknowledge critical and constructive comments by anonymous reviewers on earlier drafts of this paper.

Open Access This article is licensed under a Creative Commons Attribution 4.0 International License, which permits use, sharing, adaptation, distribution and reproduction in any medium or format, as long as you give appropriate credit to the original author(s) and the source, provide a link to the Creative Commons licence, and indicate if changes were made. The images or other third party material in this article are included in the article's Creative Commons licence, unless indicated otherwise in a credit line to the material. If material is not included in the article's Creative Commons licence and your intended use is not permitted by statutory regulation or exceeds the permitted use, you will need to obtain permission directly from the copyright holder. To view a copy of this licence, visit http://creativecommons.org/licenses/by/4.0/.

\section{References}

Angst G, Mueller KE, Kögel-Knabner I, Freeman KH, Mueller CW (2017a) Aggregation controls the stability of lignin and lipids in clay-sized particulate and mineral associated organic matter. Biogeochemistry 132:307-324. https://doi. org/10.1007/s10533-017-0304-2

Angst Ś, Mueller CW, Cajthaml T, Angst G, Lhotáková Z, Bartuška M, Špaldoňová A, Frouz J (2017b) Stabilization of soil organic matter by earthworms is connected with physical protection rather than with chemical changes of organic matter. Geoderma 289:29-35. https://doi. org/10.1016/j.geoderma.2016.11.017

Bach EM, Williams RJ, Hargreaves SK, Yang F, Hofmockel KS (2018) Greatest soil microbial diversity found in micro-habitats. Soil Biol Biochem 118:217-226. https://doi. org/10.1016/j.soilbio.2017.12.018

Bailey VL, Smith JL, Bolton H (2002) Fungal-to-bacterial ratios in soils investigated for enhanced $\mathrm{C}$ sequestration. Soil Biol Biochem 34:997-1007. https://doi.org/10.1016/s0038-0717 (02)00033-0

Bailey VL, Hicks Pries CE, Lajtha K (2019) What do we know about soil carbon destabilization? Environ Res Lett 14. https://doi.org/10.1088/1748-9326/ab2c11

Barré P, Plante AF, Cécillon L, Lutfalla S, Baudin F, Bernard S, Christensen BT, Eglin T, Fernandez JM, Houot S, Kätterer T, Le Guillou C, Macdonald A, van Oort F, Chenu C (2016) The energetic and chemical signatures of persistent soil organic matter. Biogeochemistry 130:1-12. https://doi. org/10.1007/s10533-016-0246-0

Barré P, Quénéa K, Vidal A, Cécillon L, Christensen BT, Kätterer T, Macdonald A, Petit L, Plante AF, van Oort F, Chenu C (2018) Microbial and plant-derived compounds both contribute to persistent soil organic carbon in temperate soils. Biogeochemistry 140:81-92. https://doi.org/10.1007 /s10533-018-0475-5

Baveye PC, Wander M (2019) The (bio)chemistry of soil humus and humic substances: why is the "new view" still considered novel after more than 80 years? Front Environ Sci 7. https://doi.org/10.3389/fenvs.2019.00027

Bertrand M, Barot S, Blouin M, Whalen J, de Oliveira T, RogerEstrade J (2015) Earthworm services for cropping systems. A review. Agron Sustain Dev 35:553-567. https://doi. org/10.1007/s13593-014-0269-7

Bhatnagar JM, Peay KG, Treseder KK (2018) Litter chemistry influences decomposition through activity of specific microbial functional guilds. Ecol Monogr 88:429-444. https://doi. org/10.1002/ecm.1303

Biederman LA, Boutton TW, Whisenant SG (2008) Nematode community development early in ecological restoration: the role of organic amendments. Soil Biol Biochem 40:23662374. https://doi.org/10.1016/j.soilbio.2008.05.017

Blankinship JC, Fonte SJ, Six J, Schimel JP (2016) Plant versus microbial controls on soil aggregate stability in a seasonally dry ecosystem. Geoderma 272:39-50. https://doi. org/10.1016/j.geoderma.2016.03.008

Bonanomi G, Antignani V, Capodilupo M, Scala F (2010) Identifying the characteristics of organic soil amendments that suppress soilborne plant diseases. Soil Biol Biochem 42:136-144. https://doi.org/10.1016/j.soilbio.2009.10.012

Bonanomi G, Incerti G, Abd El-Gawad AM, Cesarano G, Sarker TC, Saulino L, Lanzotti V, Saracino A, Rego FC, Mazzoleni S (2018a) Comparing chemistry and bioactivity of burned vs. decomposed plant litter: different pathways but same result? Ecology 99:158-171. https://doi.org/10.1002/ecy.2053 
Bonanomi G, Lorito M, Vinale F, Woo SL (2018b) Organic amendments, beneficial microbes, and soil microbiota: toward a unified framework for disease suppression. Annu Rev Phytopathol 56:1-20. https://doi.org/10.1146/annurevphyto-080615-100046

Bonanomi G, De Filippis F, Cesarano G, La Storia A, Zotti M, Mazzoleni S, Incerti G (2019a) Linking bacterial and eukaryotic microbiota to litter chemistry: combining next generation sequencing with 13 C CPMAS NMR spectroscopy. Soil Biol Biochem 129:110-121. https://doi.org/10.1016/j. soilbio.2018.11.013

Bonanomi G, Sarker TC, Zotti M, Cesarano G, Allevato E, Mazzoleni S (2019b) Predicting nitrogen mineralization from organic amendments: beyond $\mathrm{C} / \mathrm{N}$ ratio by $13 \mathrm{C}-\mathrm{CPMAS}$ NMR approach. Plant Soil 441:129-146. https://doi. org/10.1007/s11104-019-04099-6

Bucka FB, Kölbl A, Uteau D, Peth S, Kögel-Knabner I (2019) Organic matter input determines structure development and aggregate formation in artificial soils. Geoderma 354: 113881. https://doi.org/10.1016/j.geoderma.2019.113881

Bünemann EK, Bongiorno G, Bai Z, Creamer RE, De Deyn G, De Goede R, Fleskens L, Geissen V, Kuyper TW, Mäder P, Pulleman M, Sukkel W, van Groenigen JW, Brussaard L (2018) Soil quality - a critical review. Soil Biol Biochem 120:105-125. https://doi.org/10.1016/j.soilbio.2018.01.030

Burns RG, DeForest JL, Marxsen J, Sinsabaugh RL, Stromberger ME, Wallenstein MD, Weintraub MN, Zoppini A (2013) Soil enzymes in a changing environment: current knowledge and future directions. Soil Biol Biochem 58:216-234. https://doi. org/10.1016/j.soilbio.2012.11.009

Cassigneul A, Alletto L, Benoit P, Bergheaud V, Etiévant V, Dumény V, Le Gac AL, Chuette D, Rumpel C, Justes E (2015) Nature and decomposition degree of cover crops influence pesticide sorption: quantification and modelling. Chemosphere 119:1007-1014. https://doi.org/10.1016/j. chemosphere.2014.08.082

Cesarz S, Craven D, Dietrich C, Eisenhauer N (2016) Effects of soil and leaf litter quality on the biomass of two endogeic earthworm species. Eur J Soil Biol 77:9-16. https://doi. org/10.1016/j.ejsobi.2016.09.002

Chavarria DN, Pérez-Brandan C, Serri DL, Meriles JM, Restovich SB, Andriulo AE, Jacquelin L, Vargas-Gil S (2018) Response of soil microbial communities to agroecological versus conventional systems of extensive agriculture. Agric Ecosyst Environ 264:1-8. https://doi.org/10.1016/j. agee.2018.05.008

Conde-Cid M, Santás-Miguel V, Campillo-Cora C, Pérez-Novo C, Fernández-Calviño D (2019) Retention of propiconazole and terbutryn on acid sandy-loam soils with different organic matter and cu concentrations. J Environ Manag 248:109346. https://doi.org/10.1016/j.jenvman.2019.109346

Cong WF, Van Ruijven J, Mommer L, De Deyn GB, Berendse F, Hoffland E (2014) Plant species richness promotes soil carbon and nitrogen stocks in grasslands without legumes. J Ecol 102:1163-1170. https://doi.org/10.1111/13652745.12280

Cotrufo MF, Wallenstein MD, Boot CM, Denef K, Paul E (2013) The microbial efficiency-matrix stabilization (MEMS) framework integrates plant litter decomposition with soil organic matter stabilization: do labile plant inputs form stable soil organic matter? Glob Chang Biol 19:988-995. https://oi.org/10.1111/gcb.12113

Cotrufo MF, Ranalli MG, Haddix ML, Six J, Lugato E (2019) Soil carbon storage informed by particulate and mineralassociated organic matter. Nat Geosci 12:989-994. https://doi.org/10.1038/s41561-019-0484-6

Coward EK, Ohno T, Sparks DL (2019) Direct evidence for temporal molecular fractionation of dissolved organic matter at the Iron Oxyhydroxide Interface. Environ Sci Technol 53: 642-650. https://doi.org/10.1021/acs.est.8b04687

Curry JP, Schmidt O (2007) The feeding ecology of earthworms a review. Pedobiologia 50:463-477. https://doi.org/10.1016 j.pedobi.2006.09.001

Dai H, Chen Y, Liu K, Li Z, Qian X, Zang H, Yang X, Zhao Y, Shen Y, Li Z, Sui P (2019) Water-stable aggregates and carbon accumulation in barren sandy soil depend on organic amendment method: a three-year field study. J Clean Prod 212:393-400. https://doi.org/10.1016/j.jclepro.2018.12.013

De Graaff MA, Hornslein N, Throop HL, Kardol P, Van Diepen LTA (2019) Effects of agricultural intensification on soil biodiversity and implications for ecosystem functioning: a meta-analysis. Adv Agron 155:1-44. https://doi.org/10.1016 /bs.agron.2019.01.001

De Vries FT, Caruso T (2016) Eating from the same plate? Revisiting the role of labile carbon inputs in the soil food web. Soil Biol Biochem 102:4-9. https://doi.org/10.1016/j. soilbio.2016.06.023

De Vries FT, Bloem J, Van Eekeren N, Brusaard L, Hoffland E (2007) Fungal biomass in pastures increases with age and reduced N input. Soil Biol Biochem 39:1620-1630. https://doi.org/10.1016/j.soilbio.2007.01.013

De Vries FT, Van Groenigen JW, Hoffland E, Bloem J (2011) Nitrogen losses from two grassland soils with different fungal biomass. Soil Biol Biochem 43:997-1005. https://doi. org/10.1016/j.soilbio.2011.01.016

Demyan MS, Rasche F, Schulz E, Breulmann M, Müller T, Cadisch G (2012) Use of specific peaks obtained by diffuse reflectance Fourier transform mid-infrared spectroscopy to study the composition of organic matter in a Haplic Chernozem. Eur J Soil Sci 63:189-199. https://doi. org/10.1111/j.1365-2389.2011.01420.x

Dias ATC, Cornelissen JHC, Berg MP (2017) Litter for life: assessing the multifunctional legacy of plant traits. J Ecol 105:1163-1168. https://doi.org/10.1111/1365-2745.12763

Dijkstra JJ, Meeussen JCL, Comans RNJ (2004) Leaching of heavy metals from contaminated soils: an experimental and modeling study. Environ Sci Technol 38:4390-4395. https://doi.org/10.1021/es049885v

Dijkstra JJ, Meeussen JCL, Comans RNJ (2009) Evaluation of a generic multisurface sorption model for inorganic soil contaminants. Environ Sci Technol 43:6196-6201. https://doi. org/10.1021/es $900555 \mathrm{~g}$

Duffner A, Weng L, Hoffland E, Van Der Zee SEATM (2014) Multi-surface modeling to predict free zinc ion concentrations in low-zinc soils. Environ Sci Technol 48:5700-5708. https://doi.org/10.1021/es500257e

Dungait JAJ, Hopkins DW, Gregory AS, Whitmore AP (2012) Soil organic matter turnover is governed by accessibility not recalcitrance. Glob Chang Biol 18:1781-1796. https://doi. org/10.1111/j.1365-2486.2012.02665.x 
Eden M, Gerke HH, Houot S (2017) Organic waste recycling in agriculture and related effects on soil water retention and plant available water: a review. Agron Sustain Dev 37. https://doi.org/10.1007/s13593-017-0419-9

Erktan A, Balmot J, Merino-Martín L, Monnier Y, Pailler F, Coq S, Abiven S, Stokes A, Le Bissonnais Y (2017) Immediate and long-term effect of tannins on the stabilization of soil aggregates. Soil Biol Biochem 105:197-205. https://doi. org/10.1016/j.soilbio.2016.11.017

Feller C, Manlay RJ, Swift MJ, Bernoux M (2006) Functions, services and value of soil organic matter for human societies and the environment: a historical perspective. Geological Society Special Publication

Fierer N, Grandy AS, Six J, Paul EA (2009) Searching for unifying principles in soil ecology. Soil Biol Biochem 41:2249-2256. https://doi.org/10.1016/j.soilbio.2009.06.009

Freschet GT, Aerts R, Cornelissen JHC (2012) A plant economics spectrum of litter decomposability. Funct Ecol 26:56-65. https://doi.org/10.1111/j.1365-2435.2011.01913.x

Frostegård A, Bååth E (1996) The use of phospholipid fatty acid analysis to estimate bacterial and fungal biomass in soil. Biol Fertil Soils 22:59-65. https://doi.org/10.1007 /s003740050076

Frouz J (2018) Effects of soil macro- and mesofauna on litter decomposition and soil organic matter stabilization. Geoderma 332:161-172. https://doi.org/10.1016/j. geoderma.2017.08.039

Gao J, Jansen B, Cerli C, Helmus R, Mikutta R, Dultz S, Guggenberger G, Vogel C, Kalbitz K (2018) Organic matter coatings of soil minerals affect adsorptive interactions with phenolic and amino acids. Eur J Soil Sci 69:613-624. https://doi.org/10.1111/ejss.12562

Garciá AC, De Souza LGA, Pereira MG, Castro RN, Garciá-Mina JM, Zonta E, Lisboa FJG, Berbara RLL (2016) Structureproperty-function relationship in humic substances to explain the biological activity in plants. Sci Rep 6. https://doi. org/10.1038/srep20798

Gartner TB, Cardon ZG (2004) Decomposition dynamics in mixed-species leaf litter. Oikos 104:230-246. https://doi. org/10.1111/j.0030-1299.2004.12738.x

George PBL, Keith AM, Creer S, Barrett GL, Lebron I, Emmett BA, Robinson DA, Jones DL (2017) Evaluation of mesofauna communities as soil quality indicators in a national-level monitoring programme. Soil Biol Biochem 115:537-546. https://doi.org/10.1016/j.soilbio.2017.09.022

Giannetta B, Plaza C, Vischetti C, Cotrufo MF, Zaccone C (2018) Distribution and thermal stability of physically and chemically protected organic matter fractions in soils across different ecosystems. Biol Fertil Soils 54:671-681. https://doi. org/10.1007/s00374-018-1290-9

Gleixner G (2013) Soil organic matter dynamics: a biological perspective derived from the use of compound-specific isotopes studies. Ecol Res 28:683-695. https://doi.org/10.1007 /s11284-012-1022-9

Gondar D, López R, Antelo J, Fiol S, Arce F (2013) Effect of organic matter and $\mathrm{pH}$ on the adsorption of metalaxyl and penconazole by soils. J Hazard Mater 260:627-633. https://doi.org/10.1016/j.jhazmat.2013.06.018

Gong X, Wang S, Wang Z, Jiang Y, Hu Z, Zheng Y, Chen X, Li H, Hu F, Liu M, Scheu S (2019) Earthworms modify soil bacterial and fungal communities through enhancing aggregation and buffering pH. Geoderma 347:59-69. https://doi.org/10.1016/j.geoderma.2019.03.043

Groenenberg JE, Lofts S (2014) The use of assemblage models to describe trace element partitioning, speciation, and fate: a review. Environ Toxicol Chem 33:2181-2196. https://doi. org/10.1002/etc. 2642

Gros P, Ahmed A, Kühn O, Leinweber P (2017) Glyphosate binding in soil as revealed by sorption experiments and quantum-chemical modeling. Sci Total Environ 586:527535. https://doi.org/10.1016/j.scitotenv.2017.02.007

Gunina A, Smith AR, Kuzyakov Y, Jones DL (2017) Microbial uptake and utilization of low molecular weight organic substrates in soil depend on carbon oxidation state. Biogeochemistry 133:89-100. https://doi.org/10.1007 /s10533-017-0313-1

Gustafsson JP (2001) Modeling the acid-base properties and metal complexation of humic substances with the Stockholm humic model. J Colloid Interface Sci 244:102-112. https://doi. org/10.1006/jcis.2001.7871

Gustafsson JP, Persson I, Kleja DB, Van Schaik JWJ (2007) Binding of iron(III) to organic soils: EXAFS spectroscopy and chemical equilibrium modeling. Environ Sci Technol 41: 1232-1237. https://doi.org/10.1021/es0615730

Han L, Sun K, Keiluweit M, Yang Y, Yang Y, Jin J, Sun H, Wu F, Xing B (2019) Mobilization of ferrihydrite-associated organic carbon during Fe reduction: adsorption versus coprecipitation. Chem Geol 503:61-68. https://doi. org/10.1016/j.chemgeo.2018.10.028

Heckman K, Throckmorton H, Horwath WR, Swanston CW, Rasmussen C (2018) Variation in the molecular structure and radiocarbon abundance of mineral-associated organic matter across a lithosequence of forest soils. Soil Syst 2:36. https://doi.org/10.3390/soilsystems2020036

Hedges JI, Eglinton G, Hatcher PG, Kirchman DL, Arnosti C, Derenne S, Evershed RP, Kögel-Knabner I, De Leeuw JW, Littke R, Michaelis W, Rullkötter J (2000) The molecularlyuncharacterized component of nonliving organic matter in natural environments. Org Geochem 31:945-958. https://doi. org/10.1016/s0146-6380(00)00096-6

Hernandez-Soriano MC, Dalal RC, Warren FJ, Wang P, Green K, Tobin MJ, Menzies NW, Kopittke PM (2018) Soil organic carbon stabilization: mapping carbon speciation from intact microaggregates. Environ Sci Technol 52:12275-12284. https://doi.org/10.1021/acs.est.8b03095

Hijbeek R, Van Ittersum MK, Ten Berge HFM, Gort G, Spiegel H, Whitmore AP (2017) Do organic inputs matter - a metaanalysis of additional yield effects for arable crops in Europe. Plant Soil 411:293-303. https://doi.org/10.1007/s11104016-3031-x

Hijbeek R, Ten Berge HFM, Whitmore AP, Barkusky D, Schröder JJ, Van Ittersum MK (2018) Nitrogen fertiliser replacement values for organic amendments appear to increase with $\mathrm{N}$ application rates. Nutr Cycl Agroecosyst 110:105-115. https://doi.org/10.1007/s10705-017-9875-5

Hodge A, Robinson D, Fitter A (2000) Are microorganisms more effective than plants at competing for nitrogen? Trends Plant Sci 5:304-308. https://doi.org/10.1016/s1360-1385(00 )01656-3

Janssen BH (1984) A simple method for calculating decomposition and accumulation of 'young' soil organic matter. Plant Soil 76:297-304. https://doi.org/10.1007/bf02205588 
Janzen HH (2006) The soil carbon dilemma: shall we hoard it or use it? Soil Biol Biochem 38:419-424. https://doi. org/10.1016/j.soilbio.2005.10.008

Janzen H (2019) The future of humic substances research: preface to a debate. J Environ Qual 48:205-206. https://doi. org/10.2134/jeq2019.01.0001c

Jastrow JD, Bouton TW, Miller RM (1996) Carbon dynamics of aggregate-associated organic matter estimated by carbon-13 nuatural abundance. Soil Sci Soc Am J 60:801-807

John B, Yamashita T, Ludwig B, Flessa H (2005) Storage of organic carbon in aggregate and density fractions of silty soils under different types of land use. Geoderma 128:6379. https://doi.org/10.1016/j.geoderma.2004.12.013

Kaiser K, Kalbitz K (2012) Cycling downwards - dissolved organic matter in soils. Soil Biol Biochem 52:29-32. https://doi.org/10.1016/j.soilbio.2012.04.002

Kallenbach CM, Frey SD, Grandy AS (2016) Direct evidence for microbial-derived soil organic matter formation and its ecophysiological controls. Nat Commun 7. https://doi. org/10.1038/ncomms 13630

Keiluweit M, Bougoure JJ, Nico PS, Pett-Ridge J, Weber PK, Kleber M (2015) Mineral protection of soil carbon counteracted by root exudates. Nat Clim Chang 5:588-595. https://doi.org/10.1038/nclimate2580

Kimura A, Baptista MB, Scotti MR (2017) Soil humic acid and aggregation as restoration indicators of a seasonally flooded riparian forest under buffer zone system. Ecol Eng 98:146156. https://doi.org/10.1016/j.ecoleng.2016.10.054

Kinniburgh DG, Milne CJ, Benedetti MF, Pinheiro JP, Filius J, Koopal LK, Van Riemsdijk WH (1996) Metal ion binding by humic acid: application of the NICA-Donnan model. Environ Sci Technol 30:1687-1698. https://doi.org/10.1021 /es950695h

Kirkby CA, Kirkegaard JA, Richardson AE, Wade LJ, Blanchard C, Batten G (2011) Stable soil organic matter: a comparison of $\mathrm{C}: \mathrm{N}: \mathrm{P}: \mathrm{S}$ ratios in Australian and other world soils. Geoderma 163:197-208. https://doi.org/10.1016/j. geoderma.2011.04.010

Kleber M (2010) What is recalcitrant soil organic matter? Environ Chem 7:320-332. https://doi.org/10.1071/EN10006

Kleber M, Lehmann J (2019) Humic substances extracted by alkali are invalid proxies for the dynamics and functions of organic matter in terrestrial and aquatic ecosystems. J Environ Qual 48:207-216. https://doi.org/10.2134/jeq2019.01.0036

Kleber M, Sollins P, Sutton R (2007) A conceptual model of organo-mineral interactions in soils: self-assembly of organic molecular fragments into zonal structures on mineral surfaces. Biogeochemistry 85:9-24. https://doi.org/10.1007 /s10533-007-9103-5

Kleber M, Eusterhues K, Keiluweit M, Mikutta C, Mikutta R, Nico PS (2015) Mineral-organic associations: formation, properties, and relevance in soil environments. Adv Agron 130:1-140. https://doi.org/10.1016/bs.agron.2014.10.005

Kögel-Knabner I (2002) The macromolecular organic composition of plant and microbial residues as inputs to soil organic matter. Soil Biol Biochem 34:139-162. https://doi. org/10.1016/s0038-0717(01)00158-4

Kögel-Knabner I, Rumpel C (2018) Advances in molecular approaches for understanding soil organic matter composition, origin, and turnover: a historical overview. Adv Agron 149: 1-48. https://doi.org/10.1016/bs.agron.2018.01.003
Kopittke PM, Hernandez-Soriano MC, Dalal RC, Finn D, Menzies NW, Hoeschen C, Mueller CW (2018) Nitrogenrich microbial products provide new organo-mineral associations for the stabilization of soil organic matter. Glob Chang Biol 24:1762-1770. https://doi.org/10.1111/gcb.14009

Kramer MG, Sanderman J, Chadwick OA, Chorover J, Vitousek PM (2012) Long-term carbon storage through retention of dissolved aromatic acids by reactive particles in soil. Glob Chang Biol 18:2594-2605. https://doi.org/10.1111/j.13652486.2012.02681.x

Krause L, Biesgen D, Treder A, Schweizer SA, Klumpp E, Knief C, Siebers N (2019) Initial microaggregate formation: association of microorganisms to montmorillonite-goethite aggregates under wetting and drying cycles. Geoderma 351:250260. https://doi.org/10.1016/j.geoderma.2019.05.001

Lal R (2004) Soil carbon sequestration impacts on global climate change and food security. Science 304:1623-1627. https://doi.org/10.1126/science.1097396

Lavallee JM, Soong JL, Cotrufo MF (2020) Conceptualizing soil organic matter into particulate and mineral-associated forms to address global change in the 21st century. Glob Chang Biol 26:261-273. https://doi.org/10.1111/gcb.14859

Lehmann J, Kleber M (2015) The contentious nature of soil organic matter. Nature 528:60-68. https://doi.org/10.1038 /nature16069

Leinemann T, Preusser S, Mikutta R, Kalbitz K, Cerli C, Höschen C, Mueller CW, Kandeler E, Guggenberger G (2018) Multiple exchange processes on mineral surfaces control the transport of dissolved organic matter through soil profiles. Soil Biol Biochem 118:79-90. https://doi.org/10.1016/j. soilbio.2017.12.006

Leroy BLM, Schmidt O, Van den Bossche A, Reheul D, Moens M (2008) Earthworm population dynamics as influenced by the quality of exogenous organic matter. Pedobiologia 52:139150. https://doi.org/10.1016/j.pedobi.2008.07.001

Liang C, Amelung W, Lehmann J, Kästner M (2019) Quantitative assessment of microbial necromass contribution to soil organic matter. Glob Chang Biol 25:3578-3590. https://doi. org/10.1111/gcb.14781

Liu D, Keiblinger KM, Leitner S, Mentler A, ZechmeisterBoltenstern S (2016) Is there a convergence of deciduous leaf litter stoichiometry, biochemistry and microbial population during decay? Geoderma 272:93-100. https://doi. org/10.1016/j.geoderma.2016.03.005

Löv Å, Sjöstedt C, Larsbo M, Persson I, Gustafsson JP, Cornelis G, Kleja DB (2017) Solubility and transport of Cr(III) in a historically contaminated soil - evidence of a rapidly reacting dimeric Cr(III) organic matter complex. Chemosphere 189:709716. https://doi.org/10.1016/j.chemosphere.2017.09.088

Lubbers IM, Pulleman MM, Van Groenigen JW (2017) Can earthworms simultaneously enhance decomposition and stabilization of plant residue carbon? Soil Biol Biochem 105: 12-24. https://doi.org/10.1016/j.soilbio.2016.11.008

Lyons G, Genc Y (2016) Commercial humates in agriculture: real substance or smoke and mirrors? Agronomy 6. https://doi. org/10.3390/agronomy6040050

Mangalassery S, Kalaivanan D, Philip PS (2019) Effect of inorganic fertilisers and organic amendments on soil aggregation and biochemical characteristics in a weathered tropical soil. Soil Tillage Res 187:144-151. https://doi.org/10.1016/j. still.2018.12.008 
Marhan S, Scheu S (2005) The influence of mineral and organic fertilisers on the growth of the endogeic earthworm Octolasion tyrtaeum (Savigny). Pedobiologia 49:239-249. https://doi.org/10.1016/j.pedobi.2004.11.002

Marschner B, Brodowski S, Dreves A, Gleixner G, Gude A, Grootes PM, Hamer U, Heim A, Jandl G, Ji R, Kaiser K, Kalbitz K, Kramer C, Leinweber P, Rethemeyer J, Schäffer A, Schmidt MWI, Schwark L, Wiesenberg GLB (2008) How relevant is recalcitrance for the stabilization of organic matter in soils? J Plant Nutr Soil Sci 171:91-110. https://doi. org/10.1002/jpln.200700049

Miltner A, Bombach P, Schmidt-Brücken B, Kästner M (2012) SOM genesis: microbial biomass as a significant source. Biogeochemistry 111:41-55. https://doi.org/10.1007 /s10533-011-9658-Z

Mizuta K, Taguchi S, Sato S (2015) Soil aggregate formation and stability induced by starch and cellulose. Soil Biol Biochem 87:90-96. https://doi.org/10.1016/j.soilbio.2015.04.011

Moon J, Xia K, Williams MA (2019) Consistent proteinaceous organic matter partitioning into mineral and organic soil fractions during pedogenesis in diverse ecosystems. Biogeochemistry 142:117-135. https://doi.org/10.1007 /s10533-018-0523-1

Moorhead DL, Lashermes G, Sinsabaugh RL, Weintraub MN (2013) Calculating co-metabolic costs of lignin decay and their impacts on carbon use efficiency. Soil Biol Biochem 66: 17-19. https://doi.org/10.1016/j.soilbio.2013.06.016

Mooshammer M, Wanek W, Hämmerle I, Fuchslueger L, Hofhansl F, Knoltsch A, Schnecker J, Takriti M, Watzka M, Wild B, Keiblinger KM, Zechmeister-Boltenstern S, Richter A (2014) Adjustment of microbial nitrogen use efficiency to carbon:nitrogen imbalances regulates soil nitrogen cycling. Nat Commun 5:1-7. https://doi.org/10.1038 /ncomms4694

Murphy CJ, Baggs EM, Morley N, Wall DP, Paterson E (2015) Rhizosphere priming can promote mobilisation of N-rich compounds from soil organic matter. Soil Biol Biochem 81: 236-243. https://doi.org/10.1016/j.soilbio.2014.11.027

Nardi S, Pizzeghello D, Ertani A (2018) Hormone-like activity of the soil organic matter. Appl Soil Ecol 123:517-520. https://doi.org/10.1016/j.apsoil.2017.04.020

Olaetxea M, De Hita D, Garcia CA, Fuentes M, Baigorri R, Mora V, Garnica M, Urrutia O, Erro J, Zamarreño AM, Berbara RL, Garcia-Mina JM (2018) Hypothetical framework integrating the main mechanisms involved in the promoting action of rhizospheric humic substances on plant root- and shoot- growth. Appl Soil Ecol 123:521-537. https://doi. org/10.1016/j.apsoil.2017.06.007

Oldfield EE, Bradford MA, Wood SA (2019) Global metaanalysis of the relationship between soil organic matter and crop yields. Soil 5:15-32. https://doi.org/10.5194/soil-5-152019

Olk DC, Bloom PR, Perdue EM, McKnight DM, Chen Y, Farenhorst A, Senesi N, Chin YP, Schmitt-Kopplin P, Hertkorn N, Harir M (2019) Environmental and agricultural relevance of humic fractions extracted by alkali from soils and natural waters. J Environ Qual 48:217-232. https://doi. org/10.2134/jeq2019.02.0041

Panakoulia SK, Nikolaidis NP, Paranychianakis NV, Menon M, Schiefer J, Lair GJ, Krám P, Banwart SA (2017) Factors controlling soil structure dynamics and carbon sequestration across different climatic and lithological conditions. Adv Agron 142: 241-276. https://doi.org/10.1016/bs.agron.2016.10.008

Piccolo A (2002) The supramolecular structure of humic substances: a novel understanding of humus chemistry and implications in soil science. Adv Agron

Poeplau C, Don A, Six J, Kaiser M, Benbi D, Chenu C, Cotrufo MF, Derrien D, Gioacchini P, Grand S, Gregorich E, Griepentrog M, Gunina A, Haddix M, Kuzyakov Y, Kühnel A, Macdonald LM, Soong J, Trigalet S, Vermeire ML, Rovira P, van Wesemael B, Wiesmeier M, Yeasmin S, Yevdokimov I, Nieder R (2018) Isolating organic carbon fractions with varying turnover rates in temperate agricultural soils - a comprehensive method comparison. Soil Biol Biochem 125:10-26. https://oi.org/10.1016/j.soilbio.2018.06.025

Poirier V, Roumet C, Angers DA, Munson AD (2018) Species and root traits impact macroaggregation in the rhizospheric soil of a Mediterranean common garden experiment. Plant Soil 424: 289-302. https://doi.org/10.1007/s11104-017-3407-6

Polláková N, Šimanský V, Kravka M (2018) The influence of soil organic matter fractions on aggregates stabilization in agricultural and forest soils of selected Slovak and Czech hilly lands. J Soils Sediments 18:2790-2800. https://doi. org/10.1007/s1 1368-017-1842-x

Porre RJ, Van der Werf W, DeDeyn GB, Stomph TJ, Hoffland E (2020) Is litter decomposition enhanced in species mixtures? A meta-analysis. Soil Biol Biochem 145:107791. https://doi. org/10.1016/j.soilbio.2020.107791

Rabbi SMF, Daniel H, Lockwood PV, Macdonald C, Pereg L, Tighe M, Wilson BR, Young IM (2016) Physical soil architectural traits are functionally linked to carbon decomposition and bacterial diversity. Sci Rep:6. https://doi.org/10.1038 /srep33012

Rabot E, Wiesmeier M, Schlüter S, Vogel HJ (2018) Soil structure as an indicator of soil functions: a review. Geoderma 314 : 122-137. https://doi.org/10.1016/j.geoderma.2017.11.009

Rasmussen C, Heckman K, Wieder WR, Keiluweit M, Lawrence CR, Berhe AA, Blankinship JC, Crow SE, Druhan JL, Hicks Pries CE, Marin-Spiotta E, Plante AF, Schädel C, Schimel JP, Sierra CA, Thompson A, Wagai R (2018) Beyond clay: towards an improved set of variables for predicting soil organic matter content. Biogeochemistry 137:297-306. https://doi.org/10.1007/s10533-018-0424-3

Regelink IC, Stoof CR, Rousseva S, Weng L, Lair GJ, Kram P, Nikolaidis NP, Kercheva M, Banwart S, Comans RNJ (2015) Linkages between aggregate formation, porosity and soil chemical properties. Geoderma 247-248:24-37. https://doi. org/10.1016/j.geoderma.2015.01.022

Roarty S, Hackett RA, Schmidt O (2017) Earthworm populations in twelve cover crop and weed management combinations. Appl Soil Ecol 114:142-151. https://doi.org/10.1016/j. apsoil.2017.02.001

Rumpel C, Kögel-Knabner I (2011) Deep soil organic matter-a key but poorly understood component of terrestrial C cycle. Plant and Soil 338:143-158. https://doi.org/10.1007/s11104010-0391-5

Sanderman J, Kramer MG (2013) Differential production yet chemical similarity of dissolved organic matter across a chronosequence with contrasting nutrient availability in Hawaii. Biogeochemistry 113:259-269. https://doi. org/10.1007/s10533-012-9821-1 
Sarker TC, Incerti G, Spaccini R, Piccolo A, Mazzoleni S, Bonanomi G (2018) Linking organic matter chemistry with soil aggregate stability: insight from ${ }^{13} \mathrm{C}$ NMR spectroscopy. Soil Biol Biochem 117:175-184. https://doi.org/10.1016/j. soilbio.2017.11.011

Sarret G, Balesdent J, Bouziri L, Garnier JM, Marcus MA, Geoffroy N, Panfili F, Manceau A (2004) Zn speciation in the organic horizon of a contaminated soil by micro-X-ray fluorescence, micro- and powder-EXAFS spectroscopy, and isotopic dilution. Environ Sci Technol 38:2792-2801. https://doi.org/10.1021/es035171t

Scherber C, Eisenhauer N, Weisser WW, Schmid B, Voigt W, Fischer M, Schulze ED, Roscher C, Weigelt A, Allan E, Beler H, Bonkowski M, Buchmann N, Buscot F, Clement LW, Ebeling A, Engels C, Halle S, Kertscher I, Klein AM, Koller R, König S, Kowalski E, Kummer V, Kuu A, Lange M, Lauterbach D, Middelhoff C, Migunova VD, Milcu A, Müller R, Partsch S, Petermann JS, Renker C, Rottstock T, Sabais A, Scheu S, Schumacher J, Temperton VM, Tscharntke T (2010) Bottom-up effects of plant diversity on multitrophic interactions in a biodiversity experiment. Nature 468:553-556. https://doi.org/10.1038/nature09492

Schmidt O, Clements RO, Donaldson G (2003) Why do cereallegume intercrops support large earthworm populations? Appl Soil Ecol 22:181-190. https://doi.org/10.1016/s09291393(02)00131-2

Schmidt MWI, Torn MS, Abiven S, Dittmar T, Guggenberger G, Janssens IA, Kleber M, Kögel-Knabner I, Lehmann J, Manning DAC, Nannipieri P, Rasse DP, Weiner S, Trumbore SE (2011) Persistence of soil organic matter as an ecosystem property. Nature 478:49-56. https://doi. org/10.1038/nature10386

Schulte RPO, Creamer RE, Donnellan T, Farrelly N, Fealy R, O'Donoghue C, O'hUallachain D (2014) Functional land management: a framework for managing soil-based ecosystem services for the sustainable intensification of agriculture. Environ Sci Pol 38:45-58. https://doi.org/10.1016/j. envsci.2013.10.002

Sileshi G, Mafongoya PL (2007) Quantity and quality of organic inputs from coppicing leguminous trees influence abundance of soil macrofauna in maize crops in eastern Zambia. Biol Fertil Soils 43:333-340. https://doi.org/10.1007/s00374006-0111-8

Silva-Sánchez A, Soares M, Rousk J (2019) Testing the dependence of microbial growth and carbon use efficiency on nitrogen availability, $\mathrm{pH}$, and organic matter quality. Soil Biol Biochem 134:25-35. https://doi.org/10.1016/j. soilbio.2019.03.008

Six J, Conant RT, Paul EA, Paustian K (2002) Stabilization mechanisms of soil organic matter: implications for $\mathrm{C}$ saturation of soils. Plant Soil 241:155-176. https://doi. org/10.1023/a:1016125726789

Sokol NW, Kuebbing SE, Karlsen-Ayala E, Bradford MA (2018) Evidence for the primacy of living root inputs, not root or shoot litter, in forming soil organic carbon. New Phytol 221: 233-246. https://doi.org/10.1111/nph.15361

Sollins P, Swanston C, Kleber M, Filley T, Kramer M, Crow S, Caldwell BA, Lajtha K, Bowden R (2006) Organic C and N stabilization in a forest soil: evidence from sequential density fractionation. Soil Biol Biochem 38:3313-3324. https://doi. org/10.1016/j.soilbio.2006.04.014
Straathof AL (2015) Explorations of soil microbial processes driven by dissolved organic carbon. PhD thesis Wageningen University

Straathof AL, Chincarini R, Comans RNJ, Hoffland E (2014) Dynamics of soil dissolved organic carbon pools reveal both hydrophobic and hydrophilic compounds sustain microbial respiration. Soil Biol Biochem 79:109-116. https://doi. org/10.1016/j.soilbio.2014.09.004

Strawn DG, Baker LL (2008) Speciation of cu in a contaminated agricultural soil measured by XAFS, $\mu$-XAFS, and $\mu$-XRF. Environ Sci Technol 42:37-42. https://doi.org/10.1021 les071605z

Strickland MS, Rousk J (2010) Considering fungal: bacterial dominance in soils - methods, controls, and ecosystem implications. Soil Biol Biochem 42:1385-1395. https://doi. org/10.1016/j.soilbio.2010.05.007

Sutton R, Sposito G (2005) Molecular structure in soil humic substances: the new view. Environ Sci Technol 39:90099015. https://doi.org/10.1021/es050778q

Swift MJ, Heal OW, Anderson JM (1979) Decomposition in terrestrial ecosystems. Blackwell, Oxford

Tanaka F, Fukushima M, Kikuchi A, Yabuta H, Ichikawa H, Tatsumi K (2005) Influence of chemical characteristics of humic substances on the partition coefficient of a chlorinated dioxin. Chemosphere 58:1319-1326. https://doi.org/10.1016 /j.chemosphere.2004.10.008

Thakuria D, Schmidt O, Finan D, Egan D, Doohan FM (2010) Gut wall bacteria of earthworms: a natural selection process. ISME J 4:357-366. https://doi.org/10.1038/ismej.2009.124

Thornley JHM, Fowler D, Cannell MGR (1991) Terrestrial carbon storage resulting from $\mathrm{CO}_{2}$ and nitrogen fertilization in temperate grasslands. Plant Cell Environ 14:1007-1011. https://doi.org/10.1111/j.1365-3040.1991.tb00972.x

Tiberg C, Sjöstedt C, Gustafsson JP (2018) Metal sorption to Spodosol Bs horizons: organic matter complexes predominate. Chemosphere 196:556-565. https://doi.org/10.1016/j. chemosphere.2018.01.004

Totsche KU, Amelung W, Gerzabek MH, Guggenberger G, Klumpp E, Knief C, Lehndorff E, Mikutta R, Peth S, Prechtel A, Ray N, Kögel-Knabner I (2018) Microaggregates in soils. J Plant Nutr Soil Sci 181:104136. https://doi.org/10.1002/jpln.201600451

Tipping E, Lofts S, Sonke JE (2011) Humic ion-binding model VII: a revised parameterisation of cation-binding by humic substances. Environ Chem 8:225-235. https://doi. org/10.1071/EN11016

Van Agtmaal M, Straathof AL, Termorshuizen A, Lievens B, Hoffland E, De Boer W (2018) Volatile-mediated suppression of plant pathogens is related to soil properties and microbial community composition. Soil Biol Biochem 117: 164-174. https://doi.org/10.1016/j.soilbio.2017.11.015

Van Groenigen JW, Lubbers IM, Vos HMJ, Brown GG, De Deyn GB, Van Groenigen KJ (2014) Earthworms increase plant production: a meta-analysis. Sci Rep 4. https://doi. org/10.1038/srep06365

Venter ZS, Jacobs K, Hawkins HJ (2016) The impact of crop rotation on soil microbial diversity: a meta-analysis. Pedobiologia 59:215-223. https://doi.org/10.1016/j. pedobi.2016.04.001

Vervoort MTW, Vonk JA, Brolsma KM, Schütze W, Quist CW, De Goede RGM, Hoffland E, Bakker J, Mulder C, Hallmann 
J, Helder J (2014) Release of isothiocyanates does not explain the effects of biofumigation with Indian mustard cultivars on nematode assemblages. Soil Biol Biochem 68:200207. https://doi.org/10.1016/j.soilbio.2013.10.008

Vestergård M, Dam M, Mortensen LH, Dyckmans J, Christensen BT (2019) Natural ${ }^{13} \mathrm{C}$ abundance reveals age of dietary carbon sources in nematode trophic groups. Soil Biol Biochem 130:1-7. https://doi.org/10.1016/j. soilbio.2018.11.024

Vivelo S, Bhatnagar JM (2019) An evolutionary signal to fungal succession during plant litter decay. FEMS Microbiol Ecol 95. https://doi.org/10.1093/femsec/fiz145

Von Lützow M, Kögel-Knabner I (2010) Response to the concept paper: 'What is recalcitrant soil organic matter?' by Markus Kleber. Environ Chem 7:333-335. https://doi.org/10.1071 /EN10085

Von Lützow M, Kögel-Knabner I, Ekschmitt K, Flessa H, Guggenberger E, Marscher B (2007) SOM fractionation methods: Relevance to functional pools and to stabilizaton mechanisms. Soil Biol Biochem 39:2183-2207.https://doi. org/10.1016/j.soilbio.2007.03.007

Waksman SA, Tenney FG, Stevens KR (1928) The role of microorganisms in the transformation of organic matter in forest soils. Ecology 9:126-144

Wallenstein MD, Haddix ML, Ayres E, Steltzer H, Magrini-Bair KA, Paul EA (2013) Litter chemistry changes more rapidly when decomposed at home but converges during decomposition-transformation. Soil Biol Biochem 57:311-319. https://doi.org/10.1016/j.soilbio.2012.09.027

Wardle DA, Bardgett RD, Klironomos JN, Setälä H, Van der Putten WH, Wall DH (2004) Ecological linkages between aboveground and belowground biota. Science 304:16291633. https://doi.org/10.1126/science.1094875

Weng L, Van Riemsdijk WH, Koopal LK, Hiemstra T (2006) Adsorption of humic substances on goethite: comparison between humic acids and fulvic acids. Environ Sci Technol 40:7494-7500. https://doi.org/10.1021/es060777d
Weng L, Van Riemsdijk WH, Hiemstra T (2008) Humic nanoparticles at the oxide-water interface: interactions with phosphate ion adsorption. Environ Sci Technol 42:8747-8752. https://doi.org/10.1021/es801631d

Wickings K, Grandy AS, Reed SC, Cleveland CC (2012) The origin of litter chemical complexity during decomposition. Ecol Lett 15:1180-1188. https://doi.org/10.1111/j.14610248.2012.01837.x

Wiesmeier M, Urbanski L, Hobley E, Lang B, von Lützow M, Marin-Spiotta E, van Wesemael B, Rabot E, Ließ M, GarciaFranco N, Wollschläger U, Vogel HJ, Kögel-Knabner I (2019) Soil organic carbon storage as a key function of soils - a review of drivers and indicators at various scales. Geoderma 333:149-162. https://doi.org/10.1016/j. geoderma.2018.07.026

Woolf D, Lehmann J (2019) Microbial models with minimal mineral protection can explain long-term soil organic carbon persistence. Sci Rep 9:6522. https://doi.org/10.1038/s41598019-43026-8

Xu X, Thornton PE, Post WM (2013) A global analysis of soil microbial biomass carbon, nitrogen and phosphorus in terrestrial ecosystems. Glob Ecol Biogeogr 22:737-749. https://doi.org/10.1111/geb.12029

Yeasmin S, Singh B, Johnston CT, Sparks DL (2017) Organic carbon characteristics in density fractions of soils with contrasting mineralogies. Geochim Cosmochim Acta 218:215236. https://doi.org/10.1016/j.gca.2017.09.007

Zak DR, Holmes WE, White DC, Peacock AD, Tilman D (2003) Plant diversity, soil microbial communities, and ecosystem function: are there any links? Ecology 84:2042-2050. https://doi.org/10.1890/02-0433

Publisher's note Springer Nature remains neutral with regard to jurisdictional claims in published maps and institutional affiliations. 